Miguel Laso Martínez

Final paper minor

Pécs, 2014. 11. 26

\title{
Design of photovoltaic systems
}

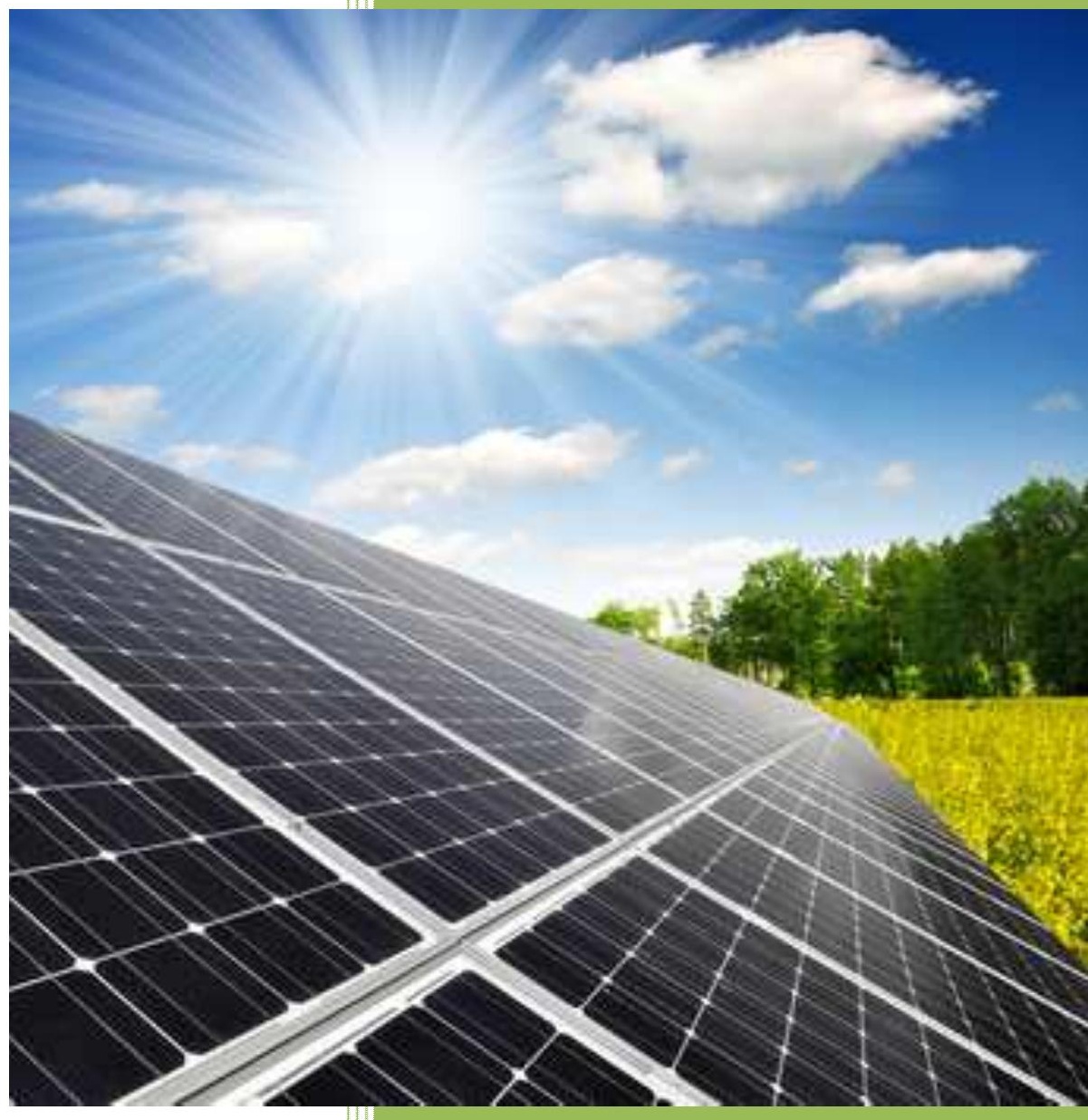

Responsible teacher: Mr George Elmer

Pollack Mihály Faculty of Engineering and Information Technology, University of Pécs 


\section{INDEX}

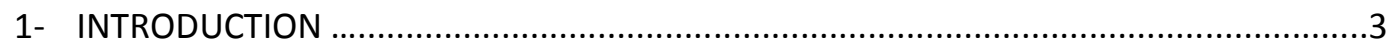

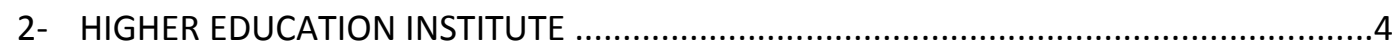

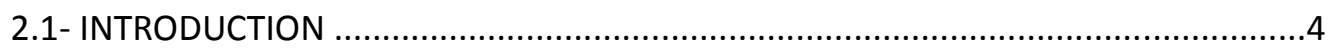

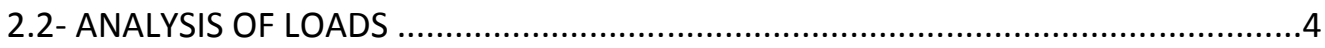

2.3- STUDY OF THE CHARACTERISTICS OF THE INSTALLATION .................................. 8

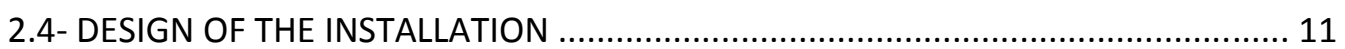

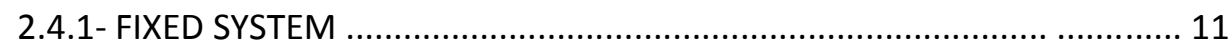

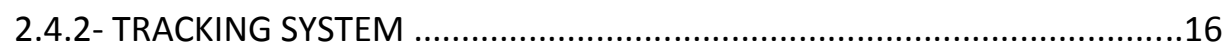

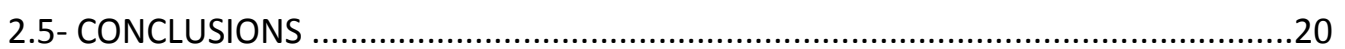

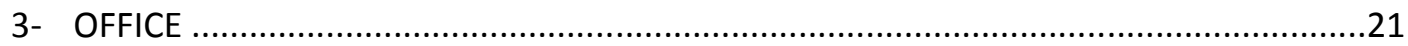

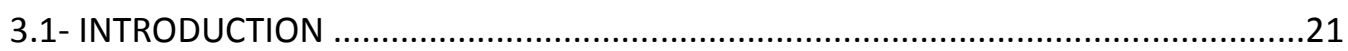

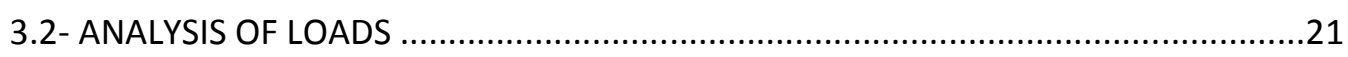

3.3- STUDY OF THE CHARACTERISTICS OF THE INSTALLATION.................................24

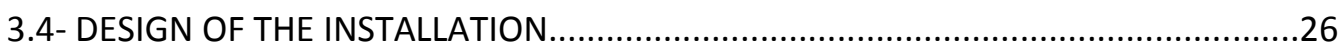

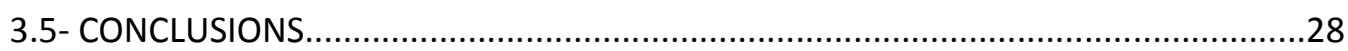

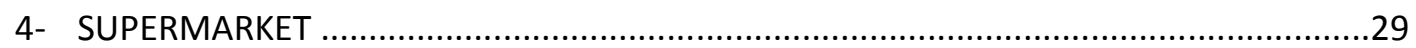

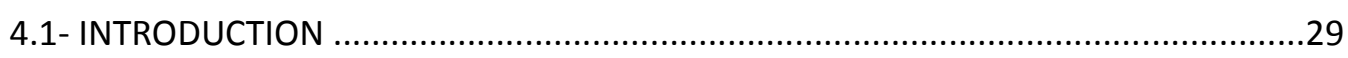

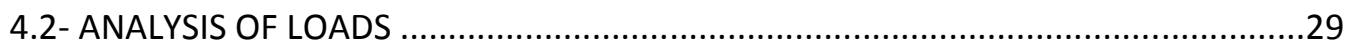

4.3- STUDY OF THE CHARACTERISTICS OF THE INSTALLATION ..................................32

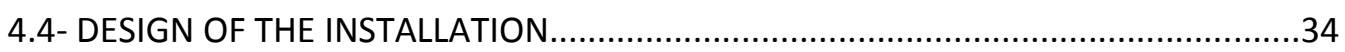

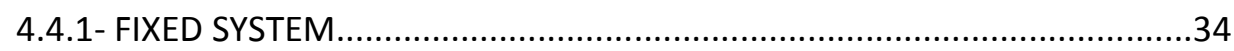

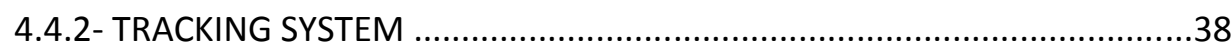

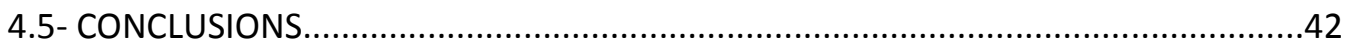

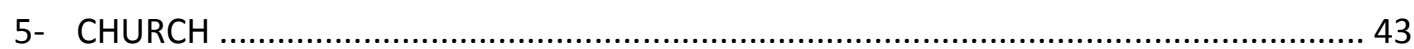

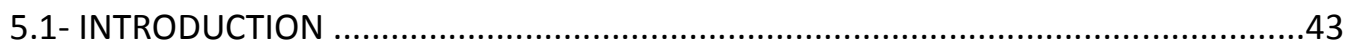

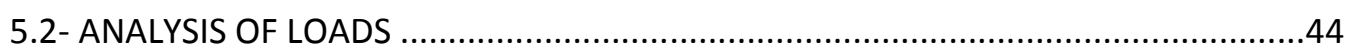

5.3- STUDY OF THE CHARACTERISTICS OF THE INSTALLATION...................................47

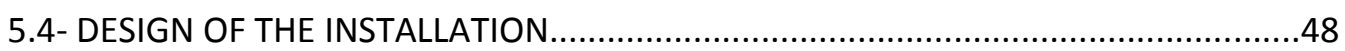

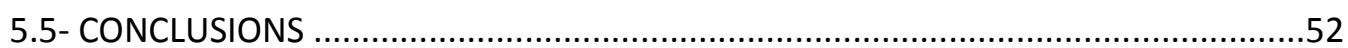

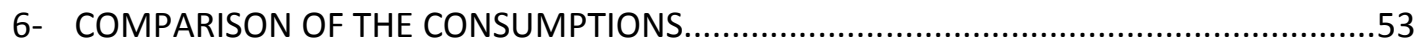

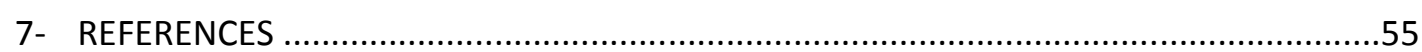




\section{1-INTRODUCTION}

Photovoltaic (PV) harvesting of solar energy is based on capturing sunlight and transforming it into electricity. This type of electricity generation does not pollute the environment as much as other types of energy production, that is why nowadays some engineers would like to improve it.

To carry out this change we use solar cells made of semiconductor materials (Silicon) in which it is artificially created a permanent electric field. These cells are connected in series or parallel forming a solar panel responsible for supplying voltage and current needed to meet the demand.

We can divide this energy in two big groups:

- Installations connected to the electric grid: This is a normal form to obtain electricity. The installation provides the energy generated to the grid, as the power plants, nuclear or hydroelectricity. Photovoltaic panels are usually located on big buildings and in big fields.

- Isolated installations: they provide energy only for an individual installation. Energy generated from photovoltaic conversion is used to cover small electricity consumption in the same place where the demand occurs. Nowadays it is an alternative form to obtain electricity than the traditional way of connecting the PV installation to the grid. It is useful for places without electric grid, street lighting, agricultural applications or air and sea traffic signs.

As other forms of energy production, solar plants have some advantages and disadvantages:

- There are not emissions of pollutants to the atmosphere.

- The silicon is abundant.

- There is no necessity for large power lines.

- It is not noisy.

- It is not necessary to use fuel.

- For large installations connected to the grid, it is necessary a big land area.

- Sometimes it is necessary a government grant because an individual installation is expensive.

- There is not much maintenance, so it is cheap.

The main objective of this project is to design and compare the installations for a higher education institute of the University of Pécs (Hungary), an office building, a supermarket and a church. I will also analyze if it is better a fix or a mobile system. 


\section{2-HIGHER EDUCATION INSTITUTE}

\section{1 - INTRODUCTION}

I am going to analyze the Pollack Mihály Faculty of Engineering and Information Technology of the University of Pécs (Hungary). This building is located in Boszorkány Street, 2, Pécs

(Hungary).

The building has four different floors:

- Floor -1: offices. This floor is smaller than the rest.

- Floor 0: main entrance, lobby, offices, classrooms, coffee shop and print room.

- Floor 1: offices and classrooms.

- Floor 2: offices and classrooms.

Each floor has different loads because they do not have the same rooms or the same uses. In the point 2.2 (Analysis of loads) I am going to calculate all the loads together, without depending on the floor.

The roof is flat, so the system will be easily installed. On the roof there are some chimneys and air extraction systems, so I need study the available area.

Finally I am going to design a tracking system because the conditions of the roof permit it.

\section{2- ANALYSIS OF LOADS}

I divide the loads into four different sections.

A- HEATING - AIR COOLING

I assume that the heating system of the faculty has two big boilers for all the building, an installation pump and different resistors. Also I suppose that the air cooling is a small system only for specific office (management and meeting room). We see this in Table 1.

Table 1. Heating related consumers at the faculty

\begin{tabular}{|l|c|}
\hline \multicolumn{1}{|c|}{ Description } & Total power \\
\hline 2 boilers (200kW each one) & $400 \mathrm{~kW}$ \\
\hline Installation pump & $20 \mathrm{~kW}$ \\
\hline Resistors & $15 \mathrm{~kW}$ \\
\hline Air cooling system & $50 \mathrm{~kW}$ \\
\hline Total & $485 \mathrm{~kW}$ \\
\hline
\end{tabular}




\section{B- ELEVATORS}

The Faculty has two elevators, each one for 8 people. I also need to consider the lighting inside the elevator. We see this in Table 2.

Table 2. Elevators related consumers at the faculty

\begin{tabular}{|l|c|}
\hline \multicolumn{1}{|c|}{ Description } & Total power \\
\hline 2 electric engines & $30 \mathrm{~kW}$ \\
\hline 4 light bulbs & $240 \mathrm{~W}$ \\
\hline Total & $30,24 \mathrm{~kW}$ \\
\hline
\end{tabular}

C- LIGHTING

I am going to use fluorescents lamps of $36 \mathrm{~W}$. We see the distribution of lamps in Table 3.

Table 3. Distribution of the lights in the faculty

\begin{tabular}{|l|c|c|c|}
\hline \multicolumn{1}{|c|}{ Room } & Number of rooms & Number of fluorescents & Total \\
\hline Main entrance & - & 15 & 15 \\
\hline Corridors & - & 150 & 150 \\
\hline Common areas & - & 10 & 10 \\
\hline Offices & 120 & 2 & 240 \\
\hline Classrooms & 20 & 10 & 200 \\
\hline Toilets & 12 & 10 & 120 \\
\hline Print room & 1 & 6 & 6 \\
\hline Coffee shop & 1 & 6 & 6 \\
\hline Reception & 1 & 3 & 3 \\
\hline Total & & & 750 \\
\hline
\end{tabular}

\section{D- INFORMATION TECHNOLOGY}

In this part there are computers, printers and projectors. All this elements are distributed in offices and information technology (IT) classrooms. We see this in Table 4.

Table 4. Technological elements in the faculty

\begin{tabular}{|l|c|c|c|}
\hline \multicolumn{1}{|c|}{ Description } & Amount & Power & Total power \\
\hline Computers & 200 & $285 \mathrm{~W}$ & $57 \mathrm{~kW}$ \\
\hline Printers & 60 & $600 \mathrm{~W}$ & $36 \mathrm{~kW}$ \\
\hline Projectors & 10 & $45 \mathrm{~W}$ & $0,45 \mathrm{~kW}$ \\
\hline Total & & & $93,45 \mathrm{~kW}$ \\
\hline
\end{tabular}


Finally, in Table 5 is the summary of all loads in the building:

Table 5: Total loads in the faculty

\begin{tabular}{|l|c|c|c|}
\hline \multicolumn{1}{|c|}{ Description } & Number of elements & Power & Total \\
\hline $\begin{array}{l}\text { Fluorescents } \\
\text { lamps }\end{array}$ & 750 & $36 \mathrm{~W}$ & $27 \mathrm{~kW}$ \\
\hline Light bulbs & 4 & $60 \mathrm{~W}$ & $0,24 \mathrm{~kW}$ \\
\hline Computers & 200 & $285 \mathrm{~W}$ & $57 \mathrm{~kW}$ \\
\hline Printers & 60 & $600 \mathrm{~W}$ & $36 \mathrm{~kW}$ \\
\hline Projectors & 10 & $45 \mathrm{~W}$ & $0,45 \mathrm{~kW}$ \\
\hline Boilers & 2 & $200 \mathrm{~kW}$ & $400 \mathrm{~kW}$ \\
\hline Installation pump & 1 & $20 \mathrm{~kW}$ & $20 \mathrm{~kW}$ \\
\hline Resistance & - & $15 \mathrm{~kW}$ & $15 \mathrm{~kW}$ \\
\hline Air cooling system & 1 & $50 \mathrm{~kW}$ & $50 \mathrm{~kW}$ \\
\hline Electric engines & 2 & $15 \mathrm{~kW}$ & $30 \mathrm{~kW}$ \\
\hline Total & & & $636 \mathrm{~kW}$ \\
\hline
\end{tabular}

All the loads will not be connected at the same time, so we have to do an approach for it.

The trend of consumption has to be determined during a day, a week and a year.

- Daily: Most of the loads are on during the day, when the faculty is full of people, from 8 a.m. to 8p.m. The rest of the time the load is lower as we can see in the Figure 1.

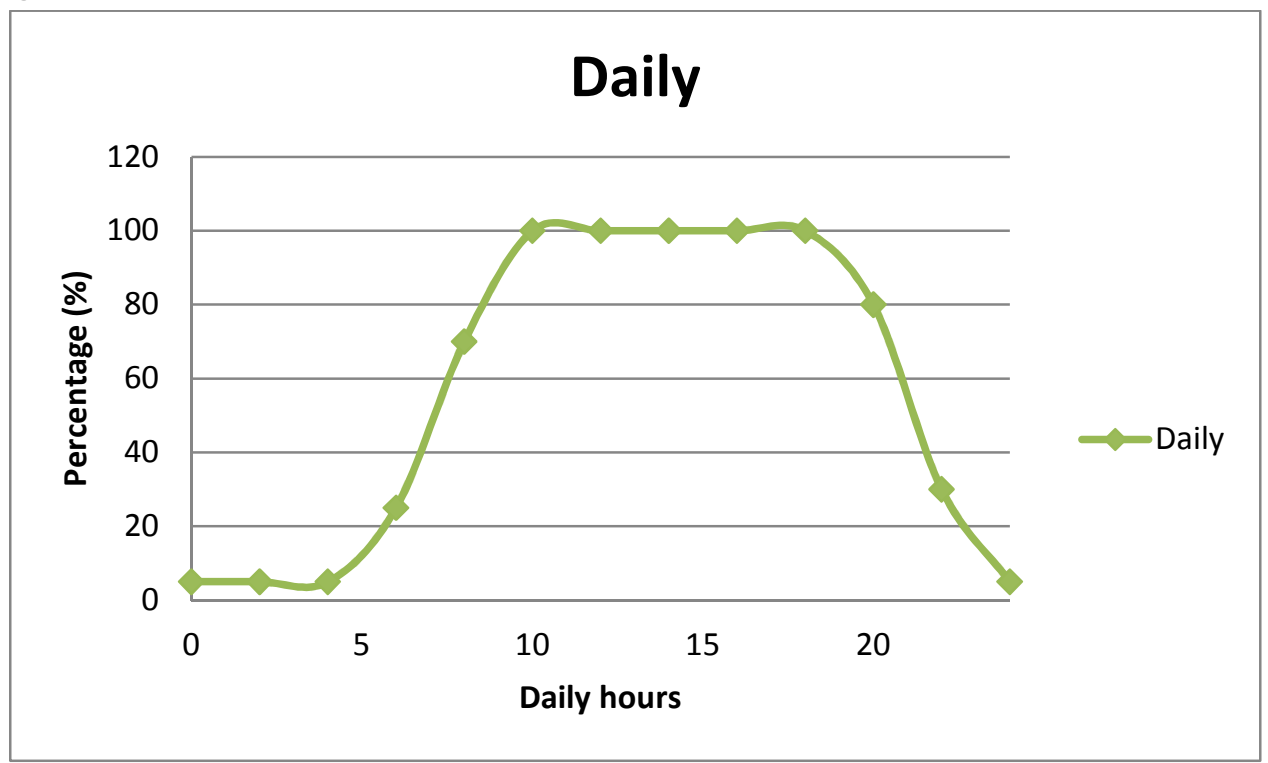

Figure 1. Daily trend of electricity consumption in the faculty 
- Weekly: Peak consumption is during the working days of the week. On Saturday there are only a few loads and on Sunday the faculty is closed. We can see it in Figure 2.

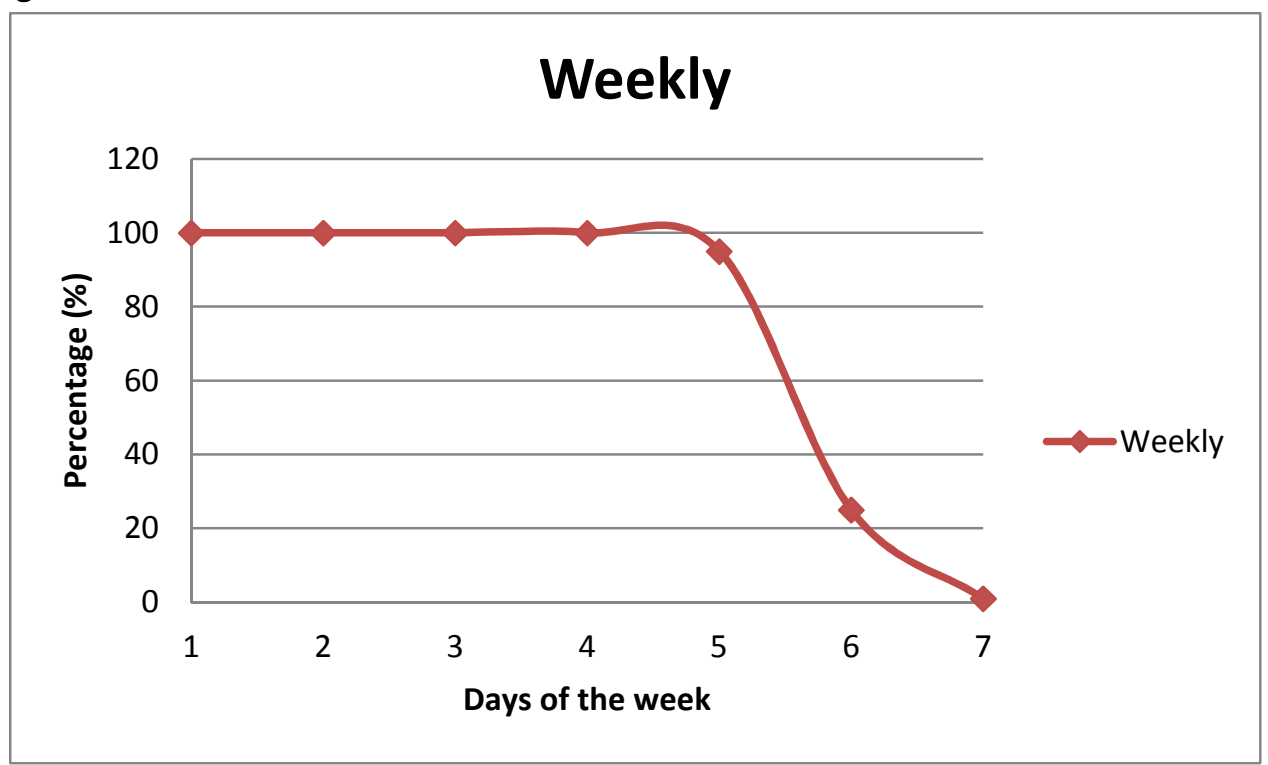

Figure 2. Weekly trend of electricity consumption in the faculty

- Yearly: from September to June I consider that the loads work on the top. In summer there are not courses and the faculty is only open for administration. Also we can see a decrease of the consumption at Christmas, when the Faculty is closed. We can see it in Figure 3.

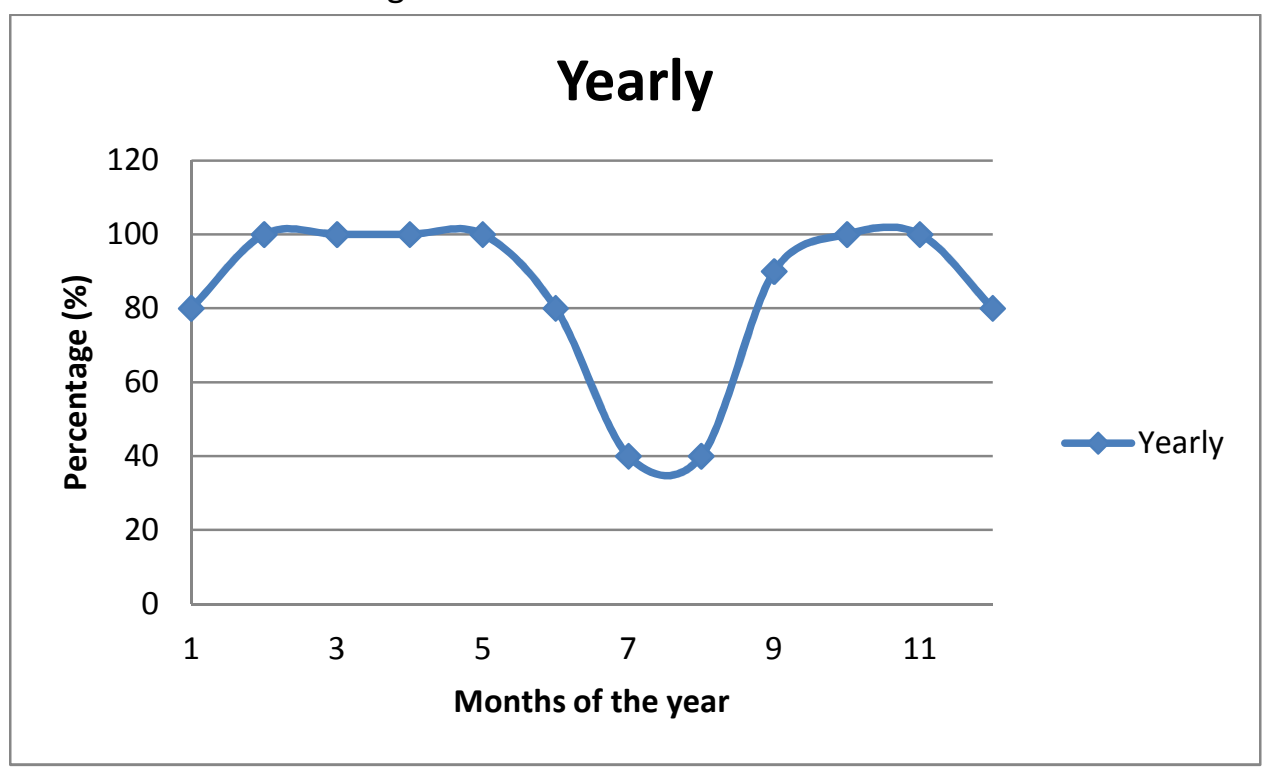

Figure 3. Yearly trend of electricity consumption in the faculty 


\section{3-STUDY OF THE CHARACTERISTICS OF THE INSTALLATION}

Once the trend of loads connected is known, I need the solar radiation reaching our photovoltaic panels, in this case in Pécs (Hungary). I am going to use the Photovoltaic Geographical Information System (PVGIS, http://re.jrc.ec.europa.eu/pvgis/). We only have to use the Europe map and follow Pécs, this software gives us the solar radiation for all the inclinations we want. Due to we only want the best option for a fixed system we tick the option "optimize slope" and I obtain that 35 o is the correct inclination.

The radiations obtained are written in Table 6:

Table 6: Radiation in Pécs for 35o

\begin{tabular}{|c|c|c|c|c|c|c|c|c|c|c|c|c|}
\hline \multicolumn{10}{|c|}{ Radiation $\mathrm{kWh} /$ día/m2 } \\
\hline & J & F & M & A & M & Jn & Jl & A & S & O & N & D \\
\hline 35 o & 1,47 & 2,23 & 3,37 & 4,08 & 4,27 & 4,39 & 4,53 & 4,31 & 3,51 & 2,93 & 1,73 & 1,16 \\
\hline
\end{tabular}

The loads of each period of the year are different because different systems are connected. Because of this I am going to analyze the loads in 3 periods.

1- July and August

During this period of time the faculty is only open for coming to the secretary to solve problems with the documents. There are not courses and it only opens in the morning. The staff does not need all the fluorescents, computers and printers. Air cooling system is connected too. We see this in Table 7.

Table 7. Analysis of loads in period 1 in the faculty

\begin{tabular}{|l|c|c|c|c|}
\hline \multicolumn{5}{|c|}{ July - August } \\
\hline \multicolumn{1}{|c|}{ Description } & Number of elements & Power & Hours & Total (kWh) \\
\hline Fluorescents lamps & 200 & $36 \mathrm{~W}$ & 5 & 36 \\
\hline Light bulbs & 4 & $60 \mathrm{~W}$ & 5 & 1,2 \\
\hline Computers & 40 & $285 \mathrm{~W}$ & 3 & 34,2 \\
\hline Printers & 10 & $600 \mathrm{~W}$ & 2 & 0,9 \\
\hline Air cooling system & 1 & $50 \mathrm{~kW}$ & 2 & 100 \\
\hline Electric engines & 2 & $15 \mathrm{~kW}$ & 1 & 30 \\
\hline Total & \multicolumn{3}{|l}{} & 202,3 \\
\hline
\end{tabular}

The faculty needs $202.3 \mathrm{kWh}$ each day but I am going to modify a bit this amount due to possible incidents in the system. I am going to consider that the efficiency of the inverter is $90 \%$ and we add a $10 \%$ more of amount.

$$
G_{1}=\frac{E_{0} \cdot T_{1}}{E_{i}}=\frac{110 \cdot 202.3}{90}=246.89 \mathrm{kWh}
$$


Where:

- $G_{1}$ is the energy with correcting factors.

- $T_{1}$ is the energy without correcting factors.

- $\quad E_{0}$ is the percentage increase.

- $\quad E_{i}$ is the efficiency of the inverter.

2- January, February, March, November and December

During this period of time the building is open all the day, so the common loads are bigger than in the summer case. Also the heating elements are needed. It is important to explain that the heating system usually works at $40-50 \%$ of its power but it get its peak at the beginning to reach the selected temperature. I can estimate that the installation pumps works about the $60 \%$ of the full time that the installation is working. We see this in Table 8.

Table 8. Analysis of loads in period 2 in the faculty

\begin{tabular}{|l|c|c|c|c|}
\hline \multicolumn{5}{|c|}{ January - February- March - November - December } \\
\hline \multicolumn{1}{|c|}{ Description } & Number of elements & Power & Hours & Total (kWh) \\
\hline Fluorescents lamps & 750 & $36 \mathrm{~W}$ & 8 & 216 \\
\hline Light bulbs & 4 & $60 \mathrm{~W}$ & 10 & 2,4 \\
\hline Computers & 200 & $285 \mathrm{~W}$ & 3 & 171 \\
\hline Printers & 60 & $600 \mathrm{~W}$ & 0,5 & 18 \\
\hline Projectors & 10 & $45 \mathrm{~W}$ & 1 & 0,45 \\
\hline Boilers & 2 & $200 \mathrm{~kW}$ & 4 & 1600 \\
\hline Installation pump & 1 & $20 \mathrm{~kW}$ & 4 & 60 \\
\hline Resistance & - & $15 \mathrm{~kW}$ & 4 & 60 \\
\hline Electric engines & 2 & $15 \mathrm{~kW}$ & 3 & 90 \\
\hline Total & - & & 2217,85 \\
\hline
\end{tabular}

I need to increase a bit the total amount with the same approximation I did in the other case.

$$
G_{2}=\frac{E_{0} \cdot T_{2}}{E_{i}}=\frac{110 \cdot 2217.85}{90}=2709.5 \mathrm{kWh}
$$


3- April, May, June, September and October

In this period of time the faculty staff does not need heating or air cooling system, so the total load will be lower. We see this in Table 9.

Table 9. Analysis of loads in period 3 in the faculty

\begin{tabular}{|l|c|c|c|c|}
\hline \multicolumn{5}{|c|}{ April - May - June - September - October } \\
\hline \multicolumn{1}{|c|}{ Description } & Number of elements & Power & Hours & Total (kWh) \\
\hline Fluorescents lamps & 750 & $36 \mathrm{~W}$ & 8 & 216 \\
\hline Light bulbs & 4 & $60 \mathrm{~W}$ & 10 & 2,4 \\
\hline Computers & 200 & $285 \mathrm{~W}$ & 3 & 171 \\
\hline Printers & 60 & $600 \mathrm{~W}$ & 0,5 & 18 \\
\hline Projectors & 10 & $45 \mathrm{~W}$ & 1 & 0,45 \\
\hline Electric engines & 2 & $15 \mathrm{~kW}$ & 3 & 90 \\
\hline Total & \multicolumn{5}{|l}{} & 497,85 \\
\hline
\end{tabular}

I use correcting factors again:

$$
G_{3}=\frac{E_{0} \cdot T_{3}}{E_{i}}=\frac{110 \cdot 497.85}{90}=607.44 \mathrm{kWh}
$$

Once the yearly trend of operation loads is known I am going to calculate which month is the most restrictive. With this value I can start to calculate the characteristics of the system, as we can see in Table 10.

Table 10. Comparison of loads and radiation during the year for the faculty

\begin{tabular}{|c|c|c|c|c|c|c|c|c|c|c|c|c|}
\hline 350 & $\mathrm{~J}$ & $\mathrm{~F}$ & $\mathrm{M}$ & $\mathrm{A}$ & $\mathrm{M}$ & $\mathrm{Jn}$ & $\mathrm{J}$ & $\mathrm{A}$ & $\mathrm{S}$ & $\mathrm{O}$ & $\mathrm{N}$ & $\mathrm{D}$ \\
\hline $\mathrm{R}_{\mathrm{t}}$ & 1,47 & 2,23 & 3,37 & 4,08 & 4,27 & 4,39 & 4,53 & 4,31 & 3,51 & 2,93 & 1,73 & 1,16 \\
\hline $\mathrm{G}_{\mathrm{t}}$ & 2709,5 & 2709,5 & 2709,5 & 607,4 & 607,4 & 607,4 & 246,9 & 246,9 & 607,4 & 607,4 & 2709,5 & 2709,5 \\
\hline $\mathrm{D}$ & 1843,2 & 1215,0 & 804,0 & 148,9 & 142,2 & 138,4 & 54,5 & 57,3 & 173,0 & 207,3 & 1566,2 & 2335,8 \\
\hline
\end{tabular}

Where:

- $R_{t}$ is the radiation in Pécs. Measurement unit: $\mathrm{kWh} /$ day $/ \mathrm{m}^{2}$

- $G_{t}$ is the energy with correcting factors. Measurement unit: $k W h / d a y$

- $\quad D$ is the relation between $R_{t}$ and $G_{t}$. Measurement unit: $m^{2}$ 
The loads of this building are huge for only a photovoltaic system, so I also need connect it to the electric grid. The contribution of solar cells will be only a bit of the needed energy, so I will calculate the maximum number of panels that I can install and after that I will obtain the percentage of contribution.

It is known that the roof of the building is flat and very big, so I am going to analyze a fixed system and a tracking system and compare which one is better.

\section{4- DESIGN OF THE INSTALLATION}

\subsection{1- FIXED SYSTEM}

I have to consider the position and location. The building has a West-East orientation, so I can install the panels facing South with an Azimuth of 10․ It is also known that the faculty does not have buildings or big trees near, so it is not going to have problems due to shadows.

We see the plan of the building with Google Maps in Figure 4.

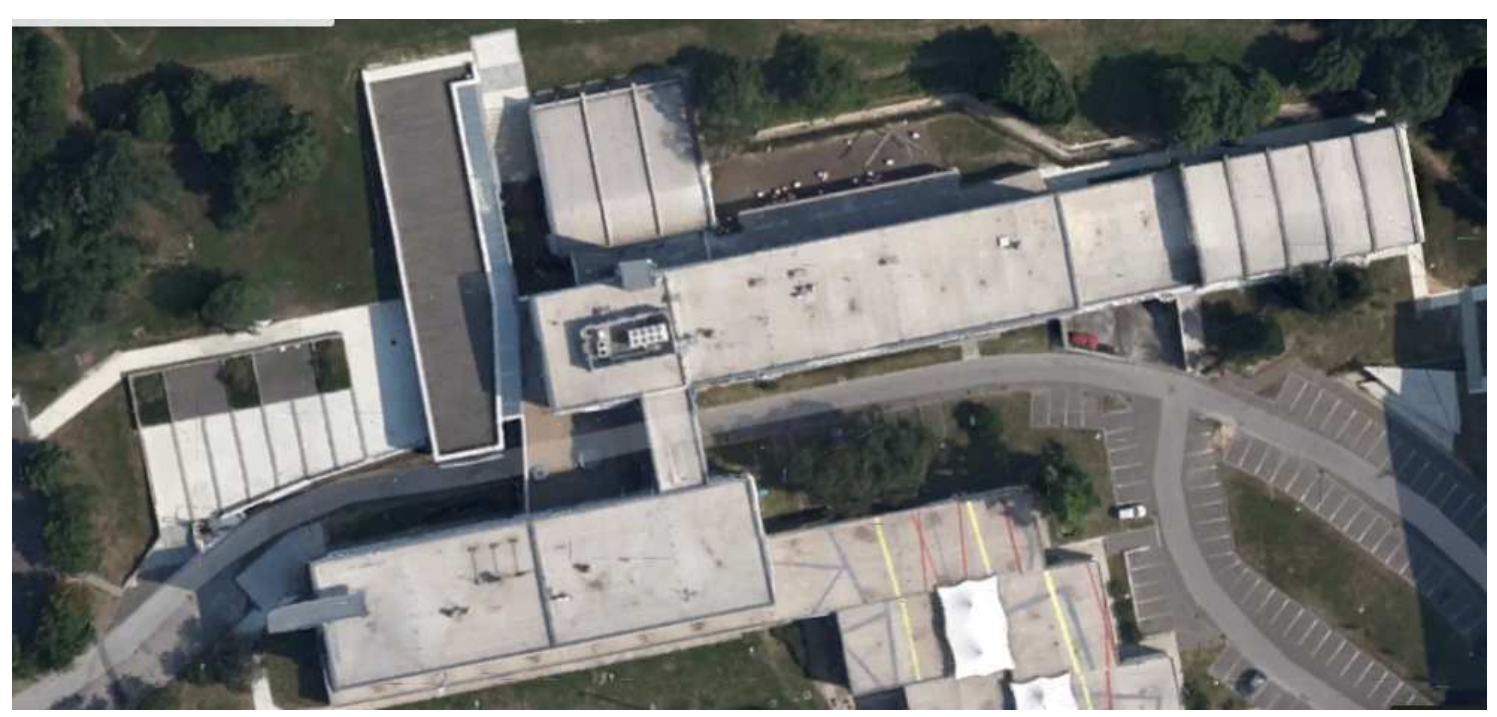

Figure 4. Top view of the faculty building

We have two different zones where I am going to install the photovoltaic panels. 
Zone 1: It is divided in the middle, so we have to separate the cells in the middle of the roof. Also there are more elements on the roof, so we have to be careful with the shadows they produce. The lengths of this zone are $20 \times 65 \mathrm{~m}$, but it is not possible to use all of this area. I am going to use the red zone to install the panels, as we can see it Figure 5.

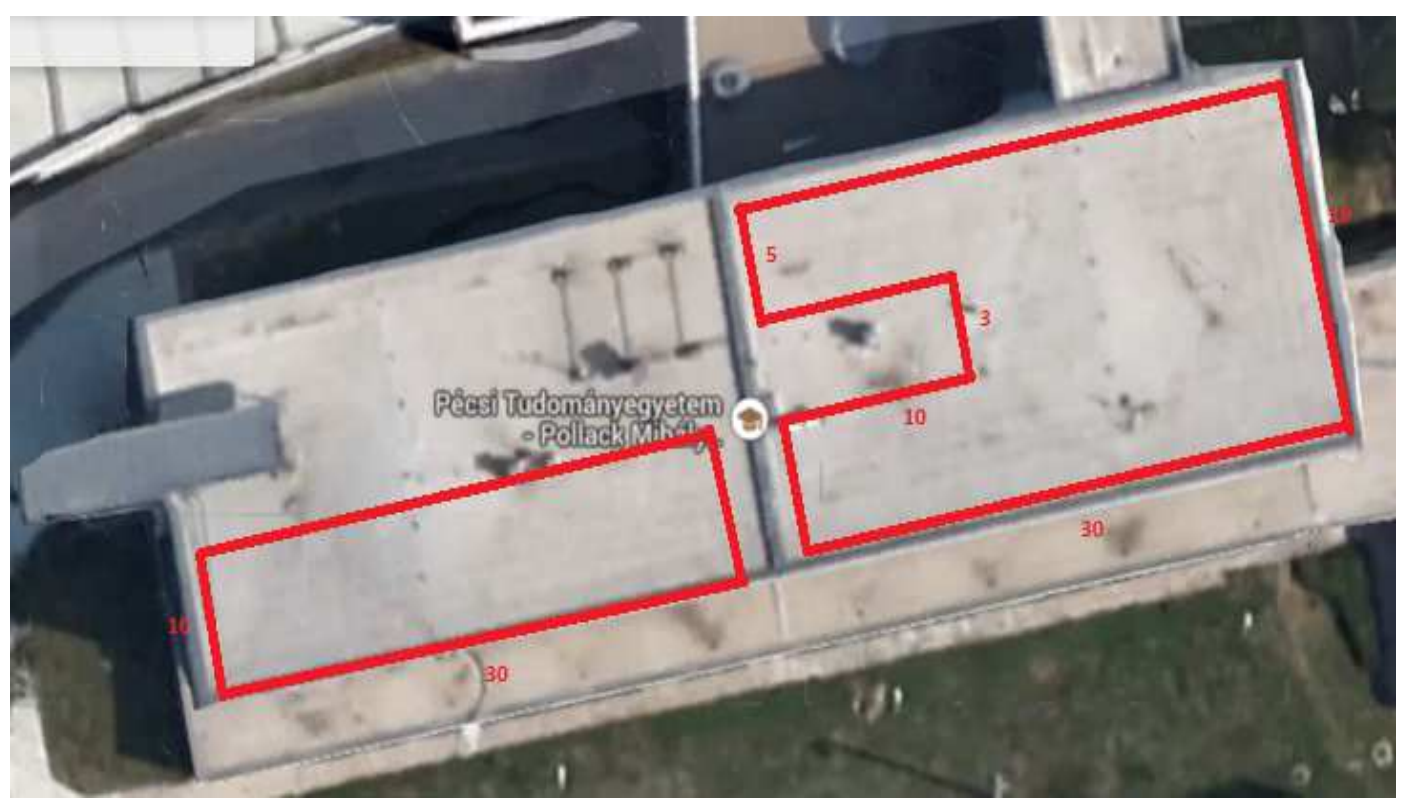

Figure 5. Top view of the zone 1 of the faculty building

Zone 2: However it has some elements in one side of the roof we can install cells. We can see the zone where we can install the panels in the Figure 6 :

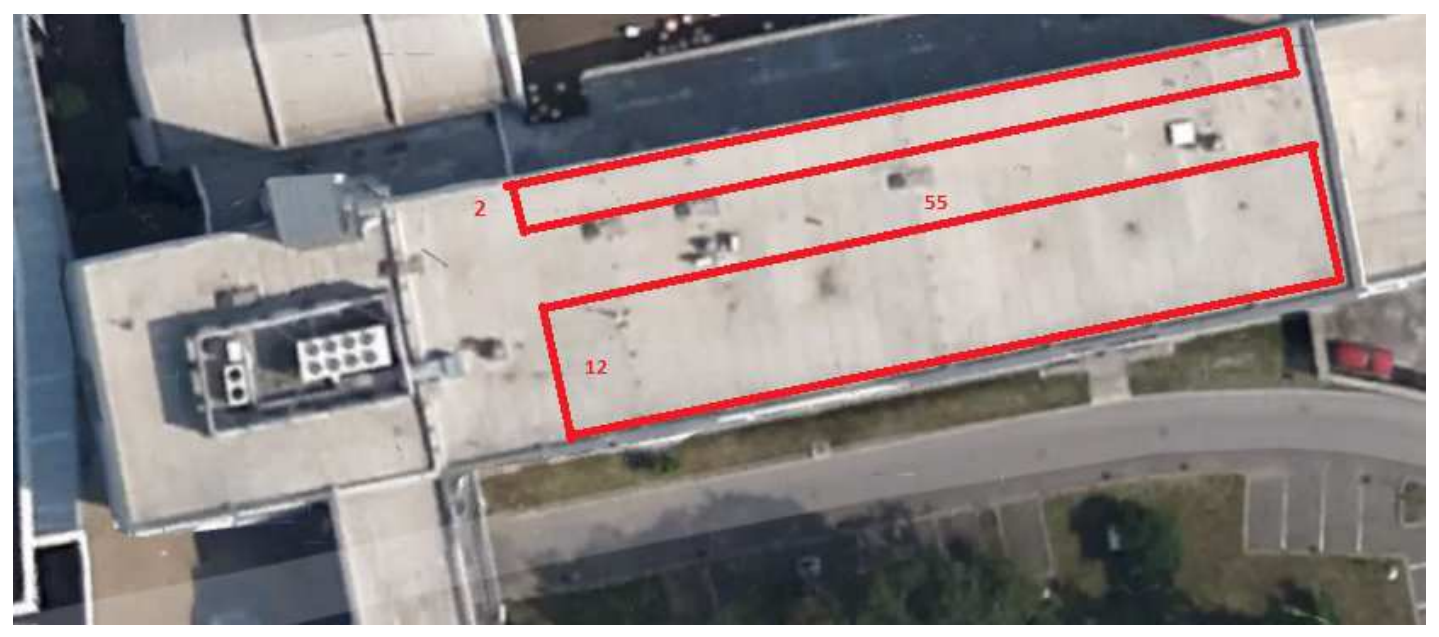

Figure 6. Top view of the zone 2 of the faculty building 
Once I have defined the available zone, I am going to select the solar cells we will use. In this case I will install photovoltaic panels Isofoton Isf-250, with the features of the Table 11:

Table 11. Features of the photovoltaic panel Isofoton Isf-250

\begin{tabular}{|c|c|}
\hline Lengths & $1667 * 994 * 45 \mathrm{~mm}$ \\
\hline Area & $1.657 \mathrm{~m}^{2}$ \\
\hline Weight & $19 \mathrm{~kg}$ \\
\hline Efficiency & $15.1 \%$ \\
\hline Voltage with open circuit & $37.8 \mathrm{~V}$ \\
\hline Current with short circuit & $8.75 \mathrm{~A}$ \\
\hline Voltage with maximum power & $30.6 \mathrm{~V}$ \\
\hline Current with maximum power & $8.17 \mathrm{~A}$ \\
\hline
\end{tabular}

Now, I have to see how many panels I can install on the roof, so I need the minimum distance between panels. We know that latitude of Pécs is $46.07 \%$. The correct form of calculate this is as we can see in Figure 7:

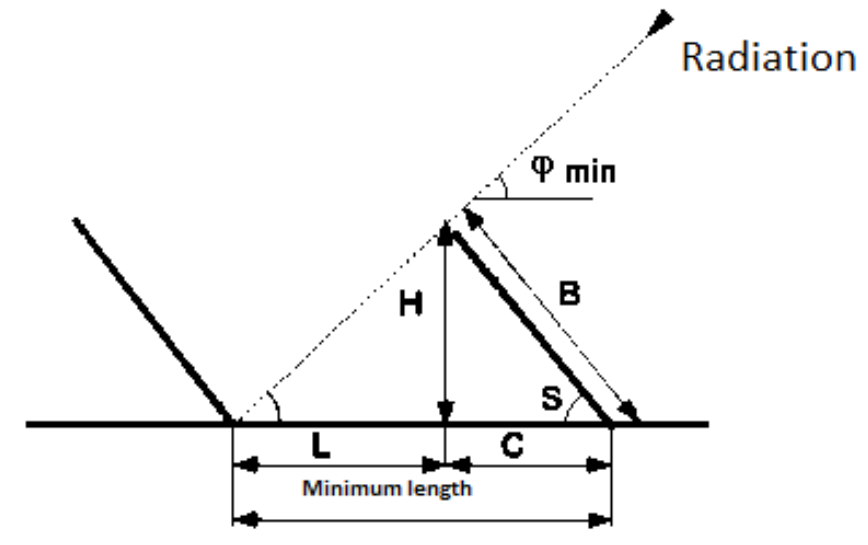

Figure 7. Incidence of radiation

Considering the position and location of the building we obtain:

$$
\begin{gathered}
C=B \cdot \cos 35^{\circ}=0.994 \cdot \cos 35^{\circ}=0.814 m \\
H=B \cdot \sin 35^{\circ}=0.994 \cdot \sin 35^{\circ}=0.57 m \\
\emptyset_{\text {min }}=90^{\circ}-46.07^{\circ}=43.93^{\circ} \\
\tan \emptyset_{\text {min }}=\frac{H}{L}=\frac{B \cdot \sin S}{D_{\min }-B \cdot \cos S} \\
D=B \cdot \cos S+\frac{B \cdot \sin S}{\tan \emptyset_{\text {min }}}=0.994 \cdot \cos 35^{\circ}+\frac{0.994 \cdot \sin 35^{\circ}}{\tan 43.93}=1.406 \mathrm{~m}
\end{gathered}
$$


To calculate the number of panels I can install, I am going to divide zone 1 in 4 different parts, as we can see in Figure 8.

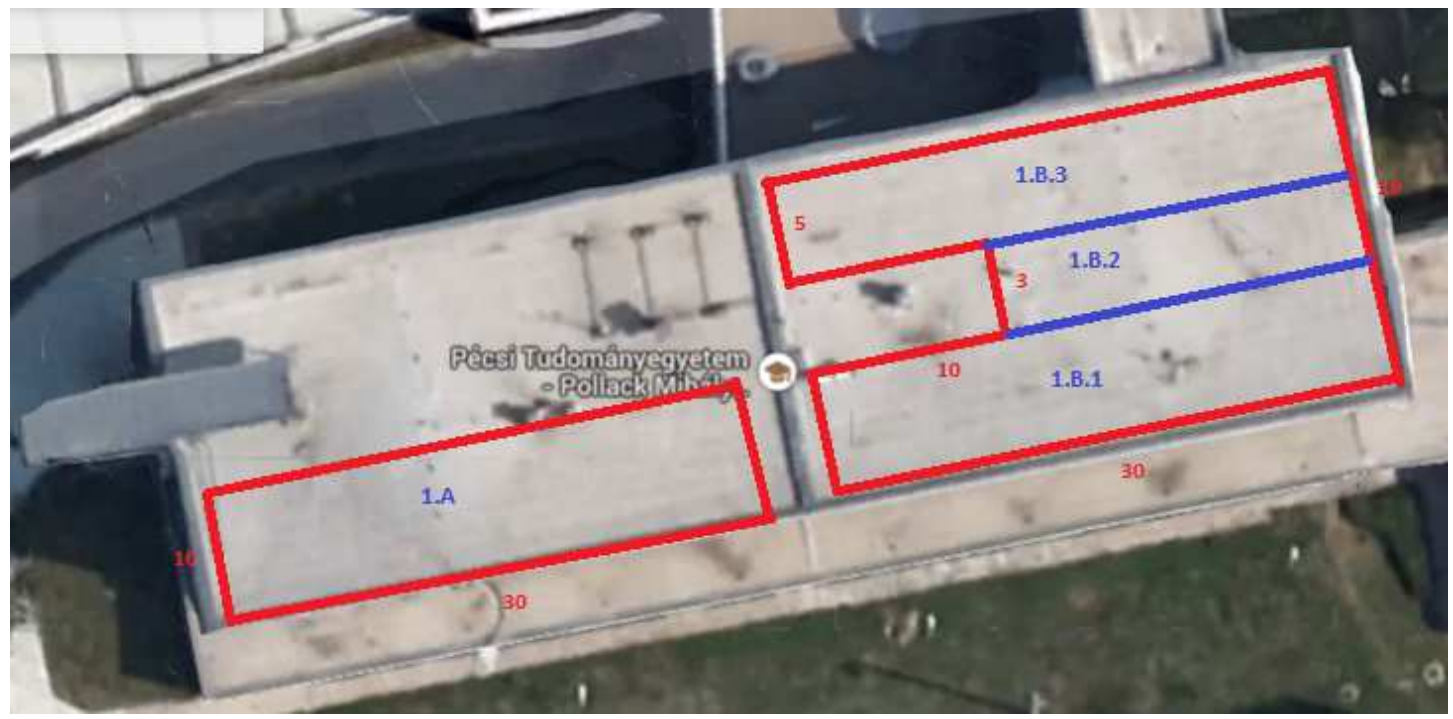

Figure 8. Top view of the divisions of zone 1 of the faculty building

Considering the lengths of the panels and the minimum distance between them, we obtain the next results:

- Zone 1.A: 6 lines of 16 panels. Total: 96 panels.

- Zone 1.B.1: 6 lines of 16 panels. Total: 96 panels.

- Zone 1.B.2: 1 line of 11 panels. Total: 11 panels.

- Zone 1.B.3: 3 lines of 16 panels. Total: 48 panels.

Thus, in zone 1 we can put 251 panels.

We can see in Figure 9 how I divide zone 2 to analyze it:

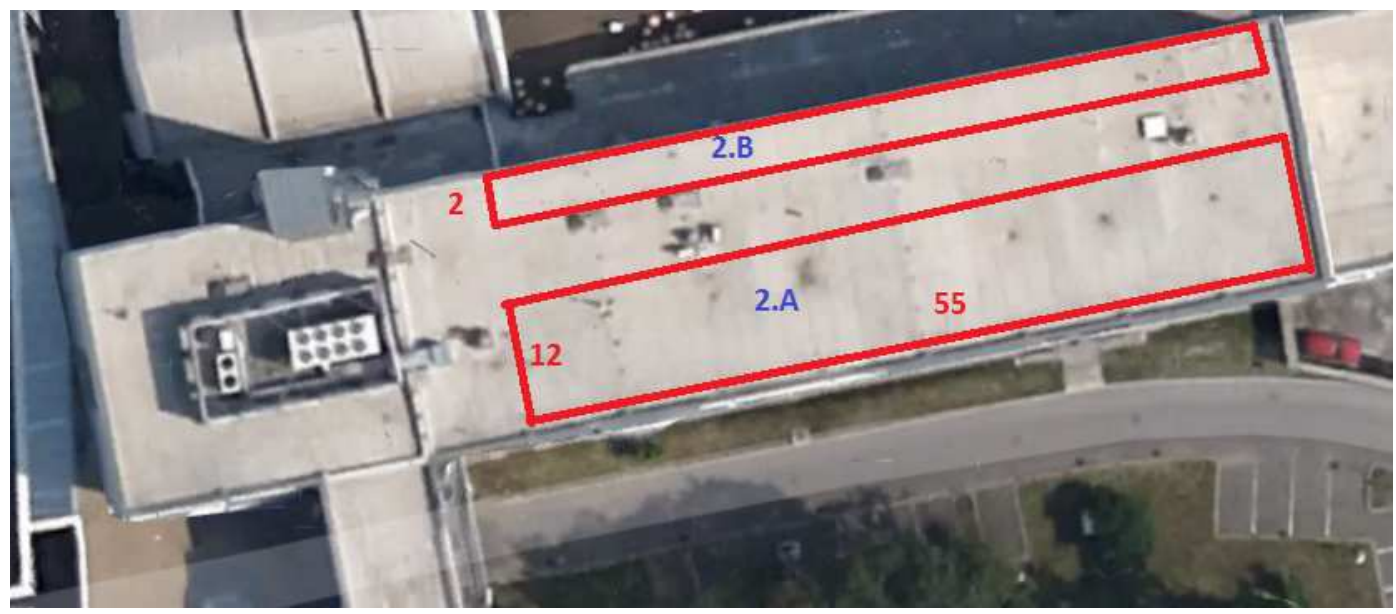

Figure 9. Top view of the divisions of zone 2 of the faculty building 
- Zone 2.A: 7 lines of 32 panels. Total: 224 panels.

- Zone 2.B: 1 line of 32 panels. Total: 32 panels.

Thus, in zone 2 we can put 256 panels.

Finally, I add the two amounts and I have a total of 507 panels.

We can see the distribution of the panels in the Figure 10:

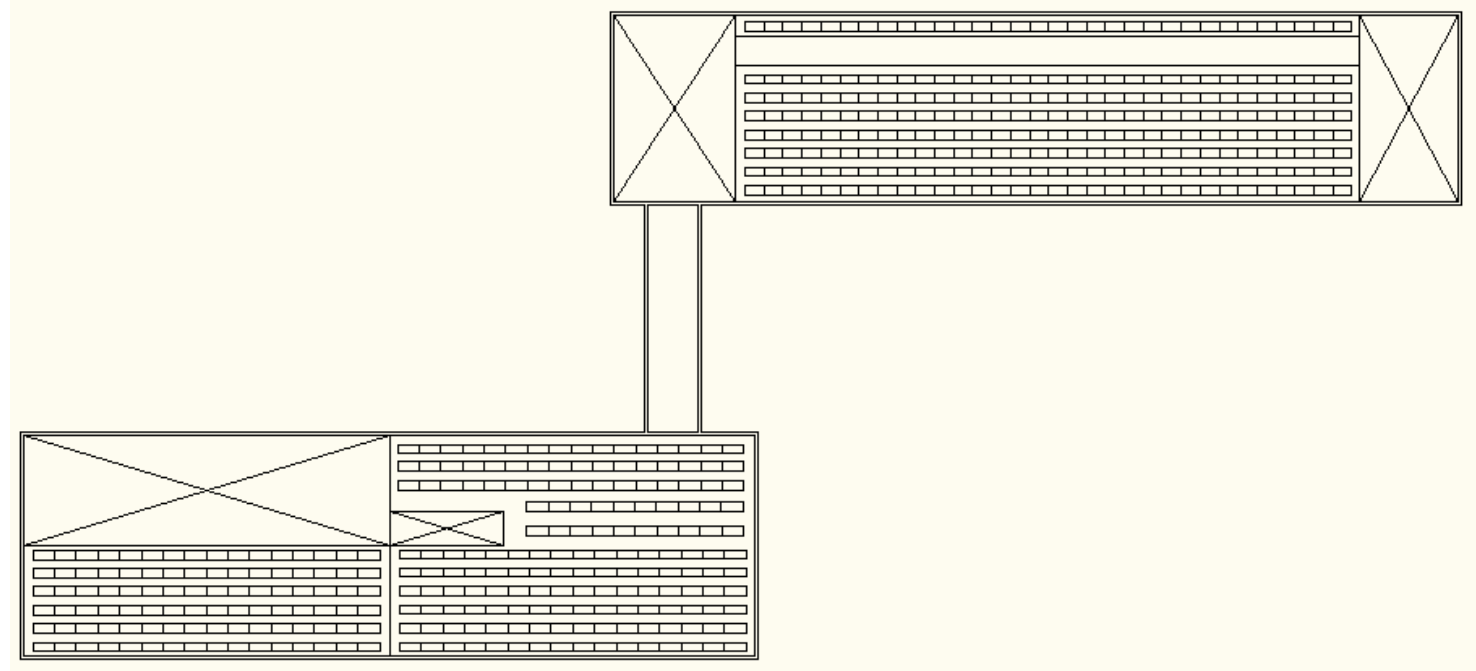

Figure 10. Distribution of the panels of the faculty building in the fixed system

Now, I calculate the total power of the installation.

$$
\text { Total power }=507 \cdot 250=126750 \mathrm{Wp}=126.75 \mathrm{kWp}
$$

Once the number of panels is calculated I am going to obtain the necessary amount of inverters. The maximum quantity of power is $126.75 \mathrm{kWp}$, so I am going to use 13 inverters Isofoton $10(10 \mathrm{~kW})$ with an efficiency of $96.8 \%$.

In this case I do not need batteries because the system is connected to the electric grid and the solar cells only support a part of the total power needed.

Now, I am going to compare the power obtained with the energy needed. We have $126.75 \mathrm{kWp}$, so in one hour we have $126.75 \mathrm{kWh}$. The results are in Table 12.

Table 12. Comparison of loads and radiation for the fixed system in the faculty

\begin{tabular}{|c|c|c|c|c|c|c|c|c|c|c|c|c|}
\hline 350 & J & F & M & A & M & Jn & Jl & A & S & O & N & D \\
\hline Rt & 1,47 & 2,23 & 3,37 & 4,08 & 4,27 & 4,39 & 4,53 & 4,31 & 3,51 & 2,93 & 1,73 & 1,16 \\
\hline Gt & 126,8 & 126,8 & 126,8 & 126,8 & 126,8 & 126,8 & 126,8 & 126,8 & 126,8 & 126,8 & 126,8 & 126,8 \\
\hline D & 86,2 & 56,8 & 37,6 & 31,1 & 29,7 & 28,9 & 28,0 & 29,4 & 36,1 & 43,3 & 73,3 & 109,3 \\
\hline
\end{tabular}


Finally, I compare the solar energy and the total energy to know the percent of the energy provided by the sun. The results are in Table 13.

Table 13. Comparison of percentage of contribution of the fixed system in the faculty

\begin{tabular}{|c|c|c|c|c|c|c|c|c|c|c|c|c|}
\hline 35 o & J & F & M & A & M & Jn & JI & A & S & O & N & D \\
\hline Solar & 86,2 & 56,8 & 37,6 & 31,1 & 29,7 & 28,9 & 28,0 & 29,4 & 36,1 & 43,3 & 73,3 & 109,3 \\
\hline Total & 1843,2 & 1215,0 & 804,0 & 148,9 & 142,2 & 138,4 & 54,5 & 57,3 & 173,0 & 207,3 & 1566,2 & 2335,8 \\
\hline$\%$ & 4,677 & 4,675 & 4,677 & 20,89 & 20,89 & 20,88 & 51,38 & 51,31 & 20,87 & 20,89 & 4,68 & 4,679 \\
\hline
\end{tabular}

\subsection{2- TRACKING SYSTEM}

The solar tracker is a mechanic device which is used to orient photovoltaic panels, because we would like that they are always perpendicular to the sunlight. Tracking sun from east in the morning to west in the evening will increase the efficiency of the solar panel up to $45 \%$.

These systems have some advantages over the fixed systems:

- They increase the efficiency of the panel.

- Easy installation and startup.

- Different options to the installation.

- Some systems can be controlled by the Internet if you have the appropriate software.

- High solar tracking precision.

- It is suitable for panels with low and high power.

- Low power consumption.

However they also have the disadvantage of being more expensive than the fixed ones.

In this case I have decided for a system with two axes and a pole for the movement and support.

For this installation I am going to use a photovoltaic panel Atersa A-150P, 150W with the features that we can see in Table 14:

Table 14. Features of the photovoltaic panel Atersa A-150P

\begin{tabular}{|c|c|}
\hline Lengths & $1476 * 659 * 35 \mathrm{~mm}$ \\
\hline Area & $0.9727 \mathrm{~m}^{2}$ \\
\hline Weight & $11.9 \mathrm{~kg}$ \\
\hline Efficiency & $15.4 \%$ \\
\hline Voltage with open circuit & $22.6 \mathrm{~V}$ \\
\hline Current with short circuit & $8.69 \mathrm{~A}$ \\
\hline Voltage with maximum power & $17.84 \mathrm{~V}$ \\
\hline Current with maximum power & $8.41 \mathrm{~A}$ \\
\hline
\end{tabular}


I am going to join 9 of these panels to form a group, and each group will be installed on a pole. So, finally we have lengths of $4428 * 1977 \mathrm{~mm}$ and the total power of each group will be $1350 \mathrm{Wp}$.

The distance between poles has to be calculated, thus I use the same expressions as in the fixed case. I calculate the distances for the two extremes situations, in the sunrise and in the sunset and in noon.

Option 1: sunrise and sunset:

The North-South distance should only be the lengths of the panels, so we need $4.6 \mathrm{~m}$. On the other hand, to calculate the East-West distance I need the expression that I used in the fixed system. The top inclination of the panel will be $70^{\circ}$, so I use this amount. We see this in Figure 11.

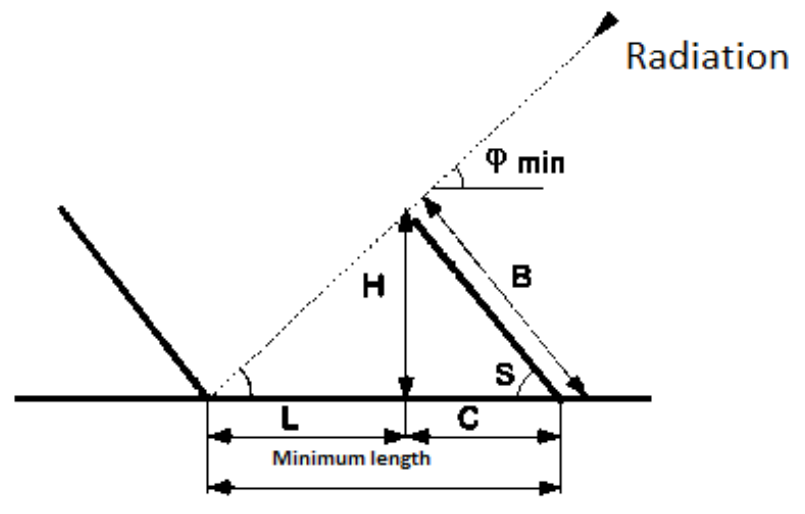

Figure 11. Incidence of radiation

$$
D_{\text {min }}=B \cdot \cos S+\frac{B \cdot \sin S}{\tan \emptyset_{\min }}=1.977 \cdot \cos 70+\frac{1.977 \cdot \sin 70}{\tan 43.93}=2.604 m
$$

Option 2: noon:

In this case the East-West distance is the length of the panels, $4.6 \mathrm{~m}$. I use the same expression to calculate the North-South distance.

$$
D_{\text {min }}=B \cdot \cos S+\frac{B \cdot \sin S}{\tan \emptyset_{\min }}=1.977 \cdot \cos 15+\frac{1.977 \cdot \sin 15}{\tan 43.93}=2.44 m
$$

So, finally I need the same separation between poles, a distance of $4.6 \mathrm{~m}$.

The objects on the roof will not disturb the installation of the poles, and they will not have problems with shadows too, because they are higher and sunlight reaches them directly.

I have to take into account the distance between poles to calculate how many I can install. I divide all the building in two zones to obtain the available area: 
- Zone 1: In this place I am going to install 4 lines of 14 poles each one. Total: 56 poles. We see this in Figure 12

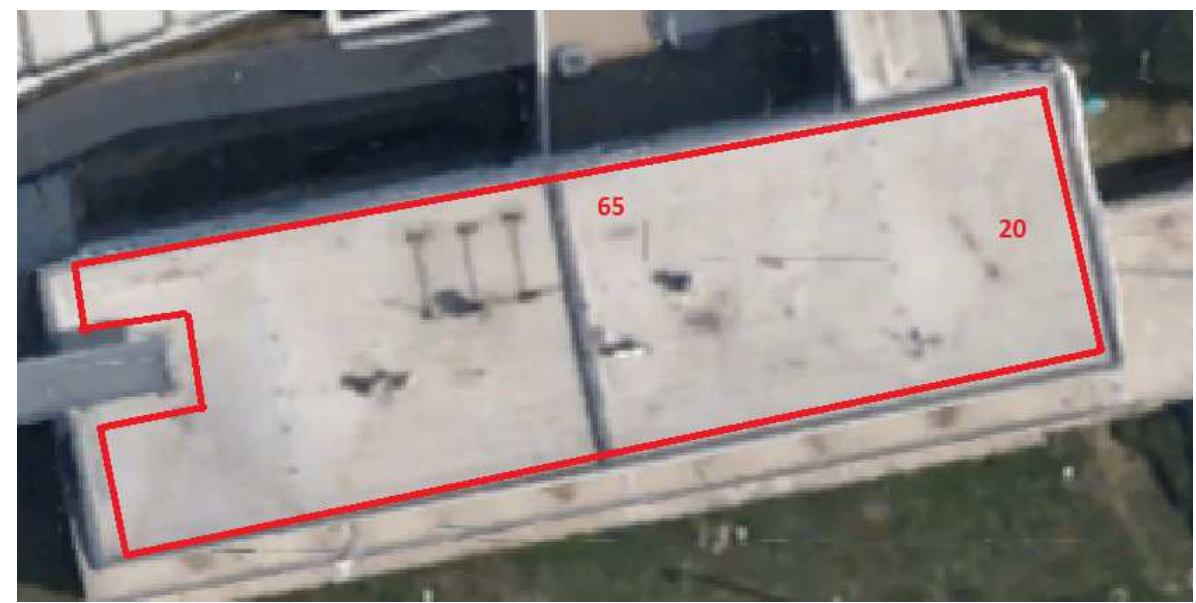

Figure 12. Top view of the zone 1 of the faculty for the tracking system

- Zone 2: I am going to install 3 lines of 12 poles each one. Total: 36 poles. Figure 13.

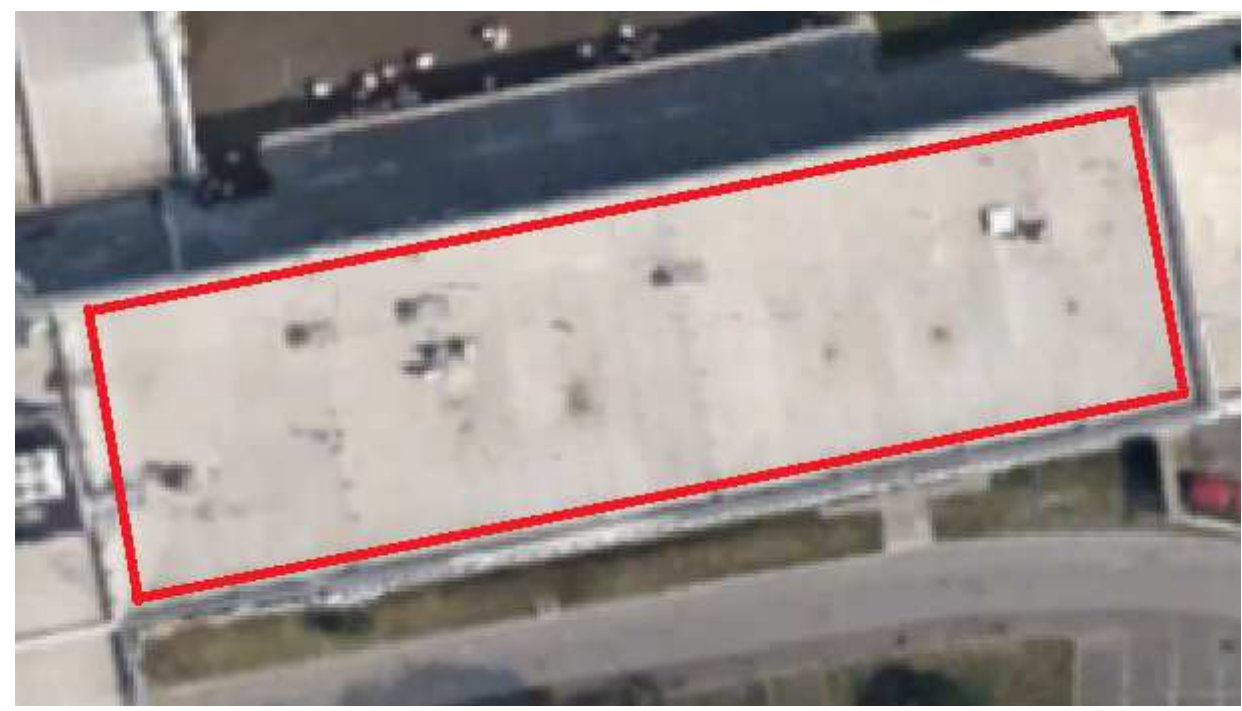

Figure 13. Top view of the zone 2 of the faculty for the tracking system 
The situation of the poles is the next:

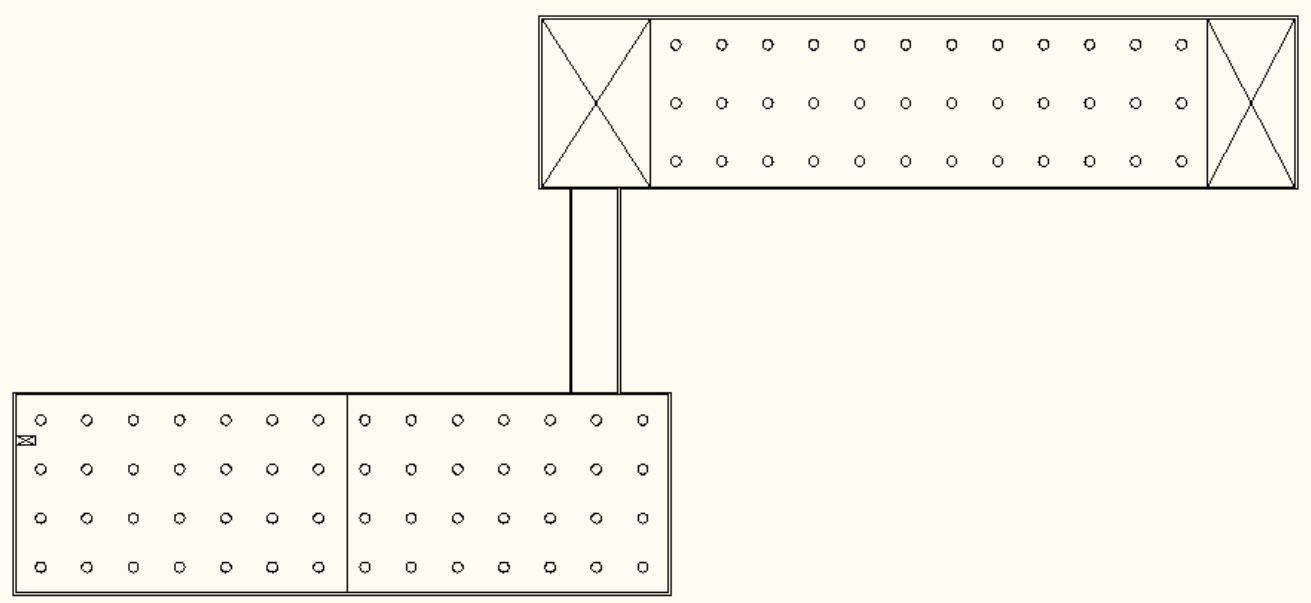

Figure 14. Distribution of the panels of the faculty building in the tracking system

Finally, we add up the two amounts and we have a total of 92 groups of panels.

$$
\text { Total power }=92 * 1350 \mathrm{Wp}=124.2 \mathrm{kWp}
$$

Once the power is calculated, I have to increase this value depending on the month with corrective factors due to the different quantity of radiation reaching in the panels during the day. In Hungary these factors for tracking systems are between 1.3 in winter and 1.8 in summer. I obtain the next results of Table 15 for each month.

Table 15. Total power produced per month in the tracking system in the faculty

\begin{tabular}{|c|c|c|c|c|c|c|c|c|c|c|c|c|}
\hline \multicolumn{10}{|c|}{ Power per month (kWp) } \\
\hline & J & F & M & A & M & Jn & Jl & A & S & O & N & D \\
\hline Factor & 1,3 & 1,4 & 1,48 & 1,65 & 1,65 & 1,75 & 1,8 & 1,8 & 1,7 & 1,6 & 1,45 & 1,3 \\
\hline $\begin{array}{c}\text { Total } \\
\text { power }\end{array}$ & 161,5 & 173,9 & 183,8 & 204,9 & 204,9 & 217,4 & 223,6 & 223,6 & 211,1 & 198,7 & 180,1 & 161,5 \\
\hline
\end{tabular}

Now the inverters for the system have to be chosen. The maximum quantity of power is $223.6 \mathrm{~kW}$, thus I am going to use 14 inverters Isofoton 23 (10kW) with an efficiency of $96.8 \%$.

In this case I do not need batteries because the system is connected to the electric grid and the solar cells only cover a part of the total power needed.

The values for the irradiation in Pécs (Hungary) for a tracking system are the in Table 16:

Table 16. Radiation per month for the tracking system in the faculty

\begin{tabular}{|c|c|c|c|c|c|c|c|c|c|c|c|c|}
\hline \multicolumn{10}{|c|}{ Radiation $\mathrm{kWh} /$ día/m2 } \\
\hline & J & F & M & A & M & Jn & Jl & A & S & O & N & D \\
\hline Tracking & 1,79 & 2,71 & 4,17 & 5,32 & 5,81 & 6,09 & 6,26 & 5,87 & 4,42 & 3,65 & 2,09 & 1,38 \\
\hline
\end{tabular}

Now, I divide this power between the irradiation to see the contribution to the system. We see this in Table 17. 
Table 17. Comparison of loads and radiation for the tracking system in the faculty

\begin{tabular}{|c|c|c|c|c|c|c|c|c|c|c|c|c|}
\hline Tracking & J & F & M & A & M & Jn & Jl & A & S & O & N & D \\
\hline Rt & 1,79 & 2,71 & 4,17 & 5,32 & 5,81 & 6,09 & 6,26 & 5,87 & 4,42 & 3,65 & 2,09 & 1,38 \\
\hline Gt & 161,5 & 173,9 & 183,8 & 204,9 & 204,9 & 217,4 & 223,6 & 223,6 & 211,1 & 198,7 & 180,1 & 161,5 \\
\hline D & 90,2 & 64,2 & 44,1 & 38,5 & 35,3 & 35,7 & 35,7 & 38,1 & 47,8 & 54,4 & 86,2 & 117,0 \\
\hline
\end{tabular}

Finally I compare the solar energy and the total energy to know the percent of the energy provided by the sun. We see this in Table 18

Table 18. Comparison of percentage of contribution of the tracking system in the faculty

\begin{tabular}{|c|c|c|c|c|c|c|c|c|c|c|c|c|}
\hline & J & F & M & A & M & Jn & Jl & A & S & O & N & D \\
\hline Tracking & 90,2 & 64,2 & 44,1 & 38,5 & 35,3 & 35,7 & 35,7 & 38,1 & 47,8 & 54,4 & 86,2 & 117,0 \\
\hline Total & 1843,2 & 1215,0 & 804,0 & 148,9 & 142,2 & 138,4 & 54,5 & 57,3 & 173,0 & 207,3 & 1566,2 & 2335,8 \\
\hline$\%$ & 4,894 & 5,281 & 5,483 & 25,87 & 24,8 & 25,79 & 65,53 & 66,47 & 27,61 & 26,26 & 5,502 & 5,009 \\
\hline
\end{tabular}

\section{5- CONCLUSIONS}

- The main elements of the fixed installation are 507 panels and 13 inverters of $10 \mathrm{~kW}$; and for the tracking system are 92 poles with 9 panels each one, and 23 inverters of $10 \mathrm{~kW}$.

- In the tracking system I can use more area because the solar panels are not installed on the floor of the roof, they are in a higher position without being shadowed by other objects of the roof.

- The comparison of the contribution of the fixed and the tracking system is in Table 19:

Table 19. Comparison of the contribution from the fixed and the tracking system

\begin{tabular}{|l|r|l|l|l|l|l|l|l|l|l|l|l|}
\hline$\%$ & J & F & M & A & M & Jn & Jl & A & S & O & N & D \\
\hline Fixed & 4,68 & 4,67 & 4,68 & 20,89 & 20,89 & 20,88 & 51,38 & 51,31 & 20,87 & 20,89 & 4,68 & 4,68 \\
\hline Tracking & 4,89 & 5,28 & 5,48 & 25,87 & 24,80 & 25,79 & 65,53 & 66,47 & 27,61 & 26,26 & 5,50 & 5,01 \\
\hline
\end{tabular}

As we can see, the contribution of the tracking system is bigger than the contribution of the fixed one.

- In summer the percentage of contribution is higher because we have more radiation from the sun and the loads are lower.

- The solar system only contributes with a small quantity of power to the system, especially in winter, but we do not have to pay the fee for this power.

- The tracking system is more expensive than the fixed one but they produce more energy. Depending on the budget we have to select one or other. 


\section{3-OFFICES}

\section{1- INTRODUCTION}

I am going to analyze a typical office building for a company. It has three floors:

- Ground floor: main entrance, reception, waiting room, coffee room.

- First floor: offices, meeting room.

- Second floor: offices.

Each floor has different loads because they do not have the same rooms or the same uses. In the point 3.2 (Analysis of loads) I am going to calculate all the loads together, without depending on the floor.

The roof has a slope of $52^{\circ}$ and the panels will be installed on it, so they will have the same inclination. In this case it is not possible install tracking system because of the features of the roof are not the best to this system.

\section{2- ANALYSIS OF LOADS}

I describe all the loads of the building together in the next tables.

A- HEATING - AIR COOLING

I assume that the air conditioning system is used for heating and for air cooling. The parts are enumerated in Table 20.

Table 20. Heating related consumers at the office

\begin{tabular}{|l|c|}
\hline \multicolumn{1}{|c|}{ Description } & Total power \\
\hline 3 systems with inside units (15kW) & $45 \mathrm{~kW}$ \\
\hline Split system & $35 \mathrm{~kW}$ \\
\hline Air heat recovery & $15 \mathrm{~kW}$ \\
\hline Extractors and ventilators & $5 \mathrm{~kW}$ \\
\hline Total & $100 \mathrm{~kW}$ \\
\hline
\end{tabular}

\section{B- ELEVATORS}

The building only has an elevator for 6 people with the loads of Table 21.

Table 21. Elevators related consumers at the office

\begin{tabular}{|l|c|}
\hline \multicolumn{1}{|c|}{ Description } & Total power \\
\hline Electric engine & $11 \mathrm{~kW}$ \\
\hline 2 light bulbs & $120 \mathrm{~W}$ \\
\hline Total & $11,12 \mathrm{~kW}$ \\
\hline
\end{tabular}


C- LIGHTING

I am going to use fluorescents lamps of 36W. We see the distribution of lamps in Table 22.

Table 22. Distribution of the lights in the office

\begin{tabular}{|l|c|c|c|}
\hline \multicolumn{1}{|c|}{ Room } & Number of rooms & Number of fluorescents & Total \\
\hline Offices & 10 & 3 & 30 \\
\hline Corridors/stairs & - & 20 & 20 \\
\hline Toilets & 6 & 4 & 24 \\
\hline Reception & 1 & 2 & 2 \\
\hline Meeting room & 1 & 6 & 6 \\
\hline Coffee room & 1 & 4 & 4 \\
\hline Total & & & 86 \\
\hline
\end{tabular}

\section{D- INFORMATION TECHNOLOGY}

In this part there are computers, printers, projectors and also a coffee machine. We see this in Table 23.

Table 23. Technological elements in the office

\begin{tabular}{|l|c|c|c|}
\hline \multicolumn{1}{|c|}{ Description } & Amount & Power & Total power \\
\hline Computers & 13 & $285 \mathrm{~W}$ & $3,7 \mathrm{~kW}$ \\
\hline Printers & 11 & $600 \mathrm{~W}$ & $6,6 \mathrm{~kW}$ \\
\hline Projectors & 1 & $45 \mathrm{~W}$ & $0,045 \mathrm{~kW}$ \\
\hline Coffee machine & 2 & $1500 \mathrm{~W}$ & $3 \mathrm{~kW}$ \\
\hline Total & & & $13.35 \mathrm{~kW}$ \\
\hline
\end{tabular}

Finally, the summary of all the loads of the building are in Table 24.

Table 24: Total loads in the office

\begin{tabular}{|c|c|c|c|}
\hline Description & Number of elements & Power & Total \\
\hline Fluorescents lamps & 86 & $36 \mathrm{~W}$ & $3,1 \mathrm{~kW}$ \\
\hline Light bulbs & 2 & $60 \mathrm{~W}$ & $0,12 \mathrm{~kW}$ \\
\hline Computers & 13 & $285 W$ & $3,7 \mathrm{~kW}$ \\
\hline Printers & 11 & $600 W$ & $6,6 \mathrm{~kW}$ \\
\hline Projectors & 1 & $45 W$ & $0,045 \mathrm{~kW}$ \\
\hline Air cooling system & 3 & $15 \mathrm{~kW}$ & $45 \mathrm{~kW}$ \\
\hline Split system & 1 & $35 \mathrm{~kW}$ & $35 \mathrm{~kW}$ \\
\hline Air heat recovery & 1 & $15 \mathrm{~kW}$ & $15 \mathrm{~kW}$ \\
\hline Extractors and ventilators & 1 & $5 \mathrm{~kW}$ & $5 \mathrm{~kW}$ \\
\hline Coffee machine & 2 & 1500W & $3 \mathrm{~kW}$ \\
\hline Electric engine & 1 & $11 \mathrm{~kW}$ & $11 \mathrm{~kW}$ \\
\hline Total & & & $127,57 \mathrm{~kW}$ \\
\hline
\end{tabular}


All the loads will not be connected at the same time, so I have to do an approach for it.

The trend of consumption has to be determined during a day, a week and a year.

- Daily: I consider that the office is open from 7a.m to 7p.m. Also the employers have a rest to having lunch from 2p.m. to 4p.m. We can see this in Figure 15.

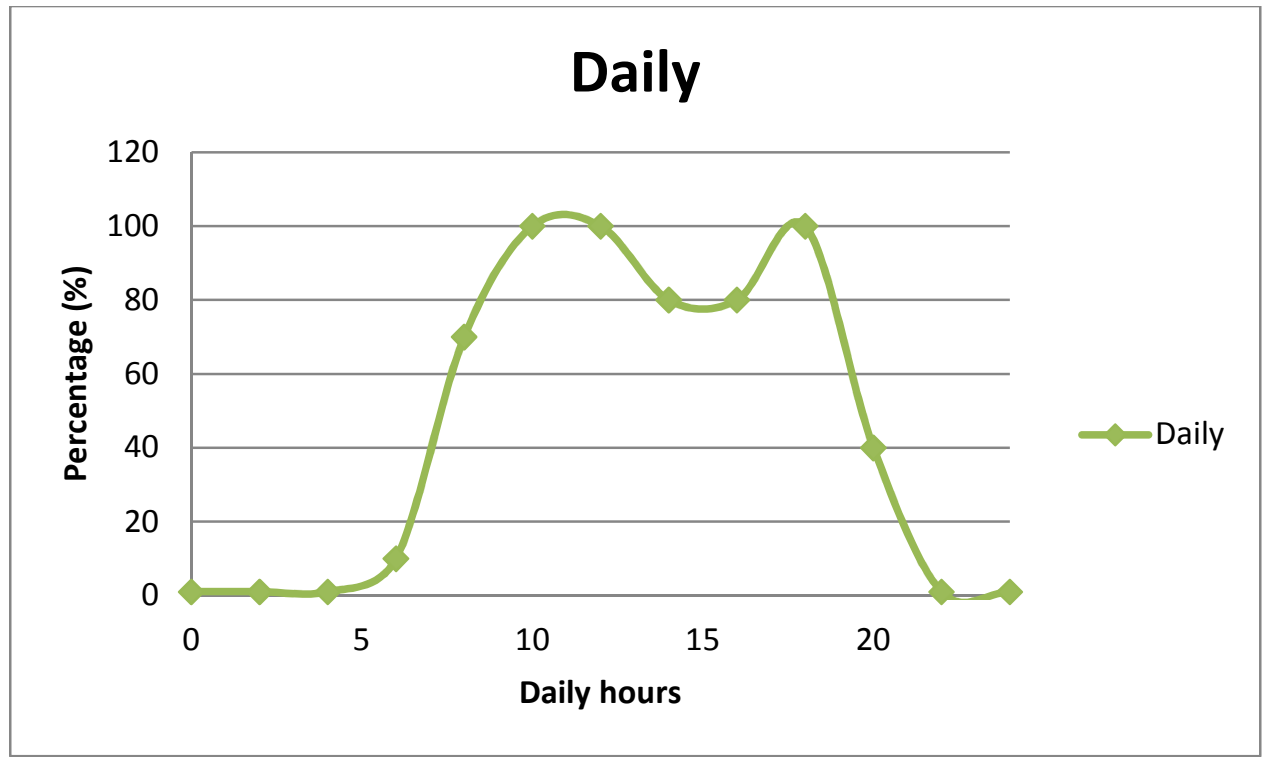

Figure 15. Daily trend of electricity consumption in the office

- Weekly: the office is open from Monday to Friday. At the weekend it is closed. We can see this in Figure 16.

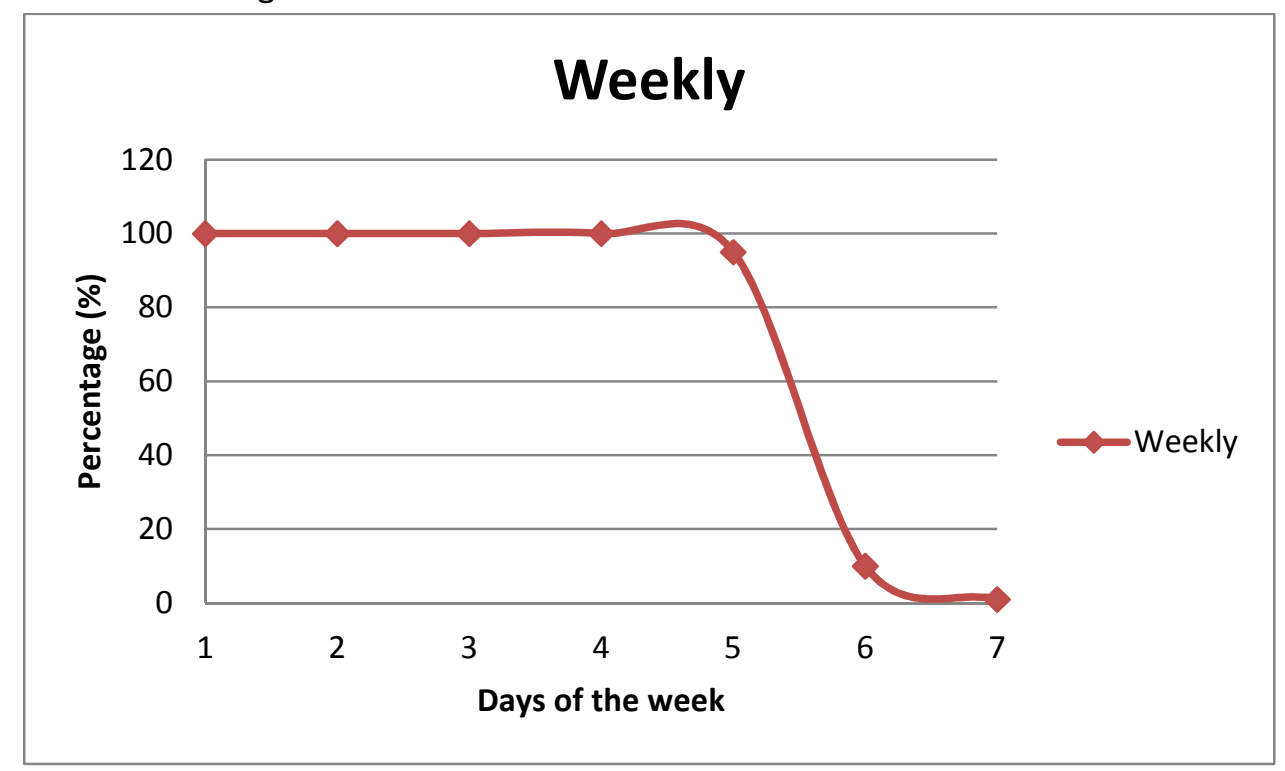

Figure 16. Weekly trend of electricity consumption in the office 
- Yearly: the office is open during all the year but in summer most of employers are on holidays. Also it is closed during Christmas. We can see this in Figure 17.

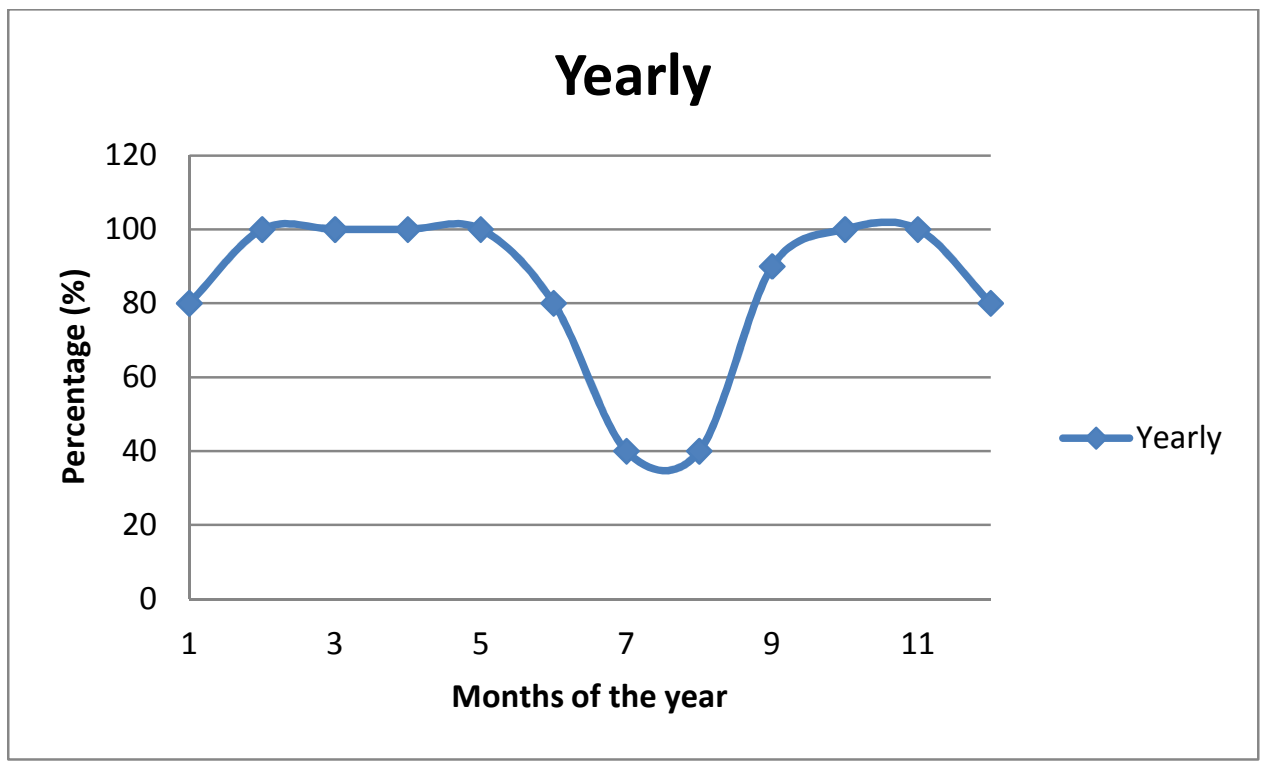

Figure 17. Yearly trend of electricity consumption in the office

\section{3- STUDY OF THE CHARACTERISTICS OF THE INSTALLATION}

The loads of each period of the year are different because we connect different systems. Because of this I am going to analyze the loads in 3 periods.

1- July-August

During this period of time some of the employers are on holidays, that is why I do not use all the common loads. On the other hand the air cooling system is connected with the splits and also the extractors and ventilators to renew the air of the office. I can consider that the splits are working the $60 \%$ of the time at the full power, and the air cooling only the $50 \%$. To approximate the loads of the ventilators and the extractors are used 30 minutes each 8 hours. The enumeration of these loads is in Table 25.

Table 25. Analysis of loads in period 1 in the office

\begin{tabular}{|l|c|c|c|c|}
\hline \multicolumn{5}{|c|}{ July - August } \\
\hline Description & Number of elements & Power & Hours & Total (kWh) \\
\hline Fluorescents lamps & 40 & $36 \mathrm{~W}$ & 5 & 7,2 \\
\hline Light bulbs & 2 & $60 \mathrm{~W}$ & 5 & 0,6 \\
\hline Computers & 5 & $285 \mathrm{~W}$ & 5 & 7,125 \\
\hline Printers & 1 & $600 \mathrm{~W}$ & 2 & 1,2 \\
\hline Air cooling system & 3 & $15 \mathrm{~kW}$ & 2,5 & 112,5 \\
\hline Split system & 1 & $35 \mathrm{~kW}$ & 3 & 105 \\
\hline Extractors and ventilators & 1 & $5 \mathrm{~kW}$ & 0,5 & 2,5 \\
\hline Coffee machine & 2 & $1,5 \mathrm{~kW}$ & 2 & 6 \\
\hline Electric engine & 1 & $11 \mathrm{~kW}$ & 0,5 & 5,5 \\
\hline Total & & & & 247,625 \\
\hline
\end{tabular}


Using the correcting factors of the efficiency of the inverter and a global increase I obtain:

$$
G_{1}=\frac{E_{0} \cdot T_{1}}{E_{i}}=\frac{110 \cdot 247.625}{90}=302.6 \mathrm{kWh}
$$

2- January, February, March, November and December

In this period the office is full of employers, so the common loads are in the top of energy needed. Also I have to include the heating system and we approximate it with a $40 \%$ of the full time. We can see these loads in Table 26.

Table 26. Analysis of loads in period 2 in the office

\begin{tabular}{|l|c|c|c|c|}
\hline \multicolumn{5}{|c|}{ January - February - March - November - December } \\
\hline \multicolumn{1}{|c|}{ Description } & Number of elements & Power & Hours & Total (kWh) \\
\hline Fluorescents lamps & 86 & $36 \mathrm{~W}$ & 8 & 24,5 \\
\hline Light bulbs & 2 & $60 \mathrm{~W}$ & 8 & 0,96 \\
\hline Computers & 13 & $285 \mathrm{~W}$ & 8 & 29,64 \\
\hline Printers & 11 & $600 \mathrm{~W}$ & 0,5 & 3,3 \\
\hline Projectors & 1 & $45 \mathrm{~W}$ & 1 & 0,045 \\
\hline Split system & 1 & $35 \mathrm{~kW}$ & 4,5 & 157,5 \\
\hline Air heat recovery & 1 & $15 \mathrm{~kW}$ & 4 & 60 \\
\hline Extractors and ventilators & 1 & $5 \mathrm{~kW}$ & 0,5 & 2,5 \\
\hline Coffee machine & 2 & $1,5 \mathrm{~kW}$ & 3 & 9 \\
\hline Electric engine & 1 & $11 \mathrm{~kW}$ & 2 & 22 \\
\hline Total & \multicolumn{3}{|l}{} & 309,445 \\
\hline
\end{tabular}

I need to increase a bit the total amount with the same approximation we did in the other case.

$$
G_{2}=\frac{E_{0} \cdot T_{2}}{E_{i}}=\frac{110 \cdot 309.445}{90}=378.21 \mathrm{kWh}
$$


3- April, May, June and September

During this period of time the heating or air cooling system is not connected. We can see this in Table 27.

Table 27. Analysis of loads in period 3 in the office

\begin{tabular}{|l|c|c|c|c|}
\hline \multicolumn{5}{c}{ April - May - June - September } \\
\hline \multicolumn{1}{|c|}{ Description } & Number of elements & Power & Hours & Total (kWh) \\
\hline Fluorescents lamps & 86 & $36 \mathrm{~W}$ & 8 & 24,5 \\
\hline Light bulbs & 2 & $60 \mathrm{~W}$ & 8 & 0,96 \\
\hline Computers & 13 & $285 \mathrm{~W}$ & 8 & 29,64 \\
\hline Printers & 11 & $600 \mathrm{~W}$ & 0,5 & 3,3 \\
\hline Projectors & 1 & $45 \mathrm{~W}$ & 1 & 0,045 \\
\hline Extractors and ventilators & 1 & $5 \mathrm{~kW}$ & 0,5 & 2,5 \\
\hline Coffee machine & 2 & $1,5 \mathrm{~kW}$ & 3 & 9 \\
\hline Electric engine & 1 & $11 \mathrm{~kW}$ & 2 & 22 \\
\hline Total & \multicolumn{3}{|l}{} & 91,945 \\
\hline
\end{tabular}

The total energy is:

$$
G_{3}=\frac{E_{0} \cdot T_{3}}{E_{i}}=\frac{110 \cdot 91.945}{90}=112.38 \mathrm{kWh}
$$

\section{4- DESIGN OF THE INSTALLATION}

The roof has an inclination of $52^{\circ}$, so I will overlay panels on the roof. Obviously the panels will have $52^{\circ}$ of inclination, and I reject the others inclinations and the flexible system.

I use PVGIS to know the radiation in Pécs to this inclination and we obtain the next results.

With this value we can start to calculate the characteristics of our system, as we can see in Table 28.

Table 28. Comparison of loads and radiation during the year for the office

\begin{tabular}{|c|c|c|c|c|c|c|c|c|c|c|c|c|}
\hline $52^{\circ}$ & J & F & M & A & M & Jn & JI & A & S & O & N & D \\
\hline Rt & 1,59 & 2,35 & 3,38 & 3,9 & 3,89 & 3,91 & 4,07 & 4,03 & 3,47 & 3,06 & 1,86 & 1,25 \\
\hline Gt & 378,2 & 378,2 & 378,2 & 112,4 & 112,4 & 112,4 & 302,6 & 302,6 & 112,4 & 112,4 & 378,2 & 378,2 \\
\hline D & 237,9 & 160,9 & 111,9 & 28,8 & 28,9 & 28,7 & 74,3 & 75,1 & 32,4 & 36,7 & 203,3 & 302,6 \\
\hline
\end{tabular}


The top view of the roof of the building is in Figure 18.

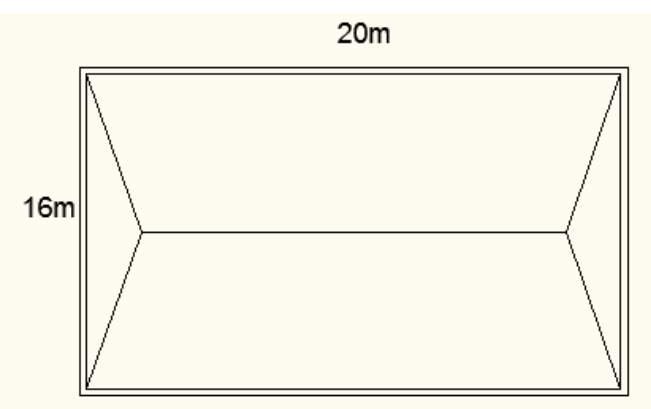

Figure 18. Top view of the roof of the building of the office

I am going to install the photovoltaic panel Isofoton Isf-250, that has the features of Table 29.

Table 29. Features of the photovoltaic panel Isofoton Isf-250

\begin{tabular}{|c|c|}
\hline Lengths & $1667 * 994^{*} 45 \mathrm{~mm}$ \\
\hline Area & $1.657 \mathrm{~m}^{2}$ \\
\hline Weight & $19 \mathrm{~kg}$ \\
\hline Efficiency & $15.1 \%$ \\
\hline Voltage with open circuit & $37.8 \mathrm{~V}$ \\
\hline Current with short circuit & $8.75 \mathrm{~A}$ \\
\hline Voltage with maximum power & $30.6 \mathrm{~V}$ \\
\hline Current with maximum power & $8.17 \mathrm{~A}$ \\
\hline
\end{tabular}

Now I calculate the available area to put the panels and I obtain approximately a square of $16 \times 10 \mathrm{~m}$. Comparing this lengths with the ones of the panels with obtain that we can put 10 lines of 9 panels each one. The scheme of the roof is in Figure 19.

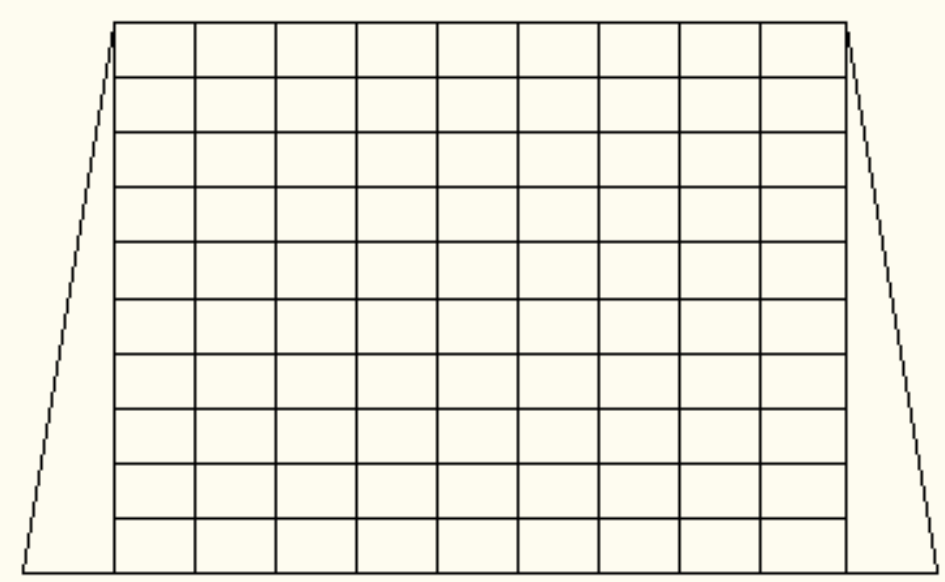

Figure 19. View of the distribution of the panels on the roof of the office

It is not necessary space between the cells because they are nail down the roof. 
The total power we have is:

$$
\text { Power }=250 \cdot 90=22500 W p=22.5 \mathrm{kWp}
$$

It is not possible to install all the necessary panels to cover all the power demand, so the system will be mixed; some energy will be taken from the solar installation and the rest from the electric grid.

To calculate the needed inverters is necessary taking into account the total power obtained with the photovoltaic panels. So I only need to invest a maximum of $22.5 \mathrm{kWp}$. I select 5 inverters Isofoton $5(5 \mathrm{kWp})$, with an efficiency of $97 \%$.

Finally I can calculate the percentage of the solar system to cover the needed loads. The results are in Table 30.

Table 30. Comparison of loads and radiation for the fixed system in the office

\begin{tabular}{|c|c|c|c|c|c|c|c|c|c|c|c|c|}
\hline 529 & J & F & M & A & M & Jn & Jl & A & S & O & N & D \\
\hline Rt & 1,59 & 2,35 & 3,38 & 3,9 & 3,89 & 3,91 & 4,07 & 4,03 & 3,47 & 3,06 & 1,86 & 1,25 \\
\hline Gt & 22,5 & 22,5 & 22,5 & 22,5 & 22,5 & 22,5 & 22,5 & 22,5 & 22,5 & 22,5 & 22,5 & 22,5 \\
\hline D & 14,2 & 9,6 & 6,7 & 5,8 & 5,8 & 5,8 & 5,5 & 5,6 & 6,5 & 7,4 & 12,1 & 18,0 \\
\hline
\end{tabular}

And the percentage is obtained is in Table 31.

Table 31. Comparison of percentage of contribution of the fixed system in the office

\begin{tabular}{|c|c|c|c|c|c|c|c|c|c|c|c|c|}
\hline & J & F & M & A & M & Jn & Jl & A & S & O & N & D \\
\hline Fixed & 14,2 & 9,6 & 6,7 & 5,8 & 5,8 & 5,8 & 5,5 & 5,6 & 6,5 & 7,4 & 12,1 & 18,0 \\
\hline Total & 237,9 & 160,9 & 111,9 & 28,8 & 28,9 & 28,7 & 74,3 & 75,1 & 32,4 & 36,7 & 203,3 & 302,6 \\
\hline$\%$ & 5,95 & 5,95 & 5,95 & 20,02 & 20,02 & 20,02 & 7,44 & 7,44 & 20,02 & 20,02 & 5,95 & 5,95 \\
\hline
\end{tabular}

\section{5- CONCLUSIONS}

- The main elements of the installation are 90 panels and 5 inverters of $5 \mathrm{~kW}$.

- If we have any problem with the solar installation we should have energy as well because we are connected to the grid. Of course, the same advantage but in the other side, if we have problems with the grid we can support the system with the solar cells.

- The panels are only installed facing to the South because it is the correct form.

- In this case it is not necessary use batteries because the system is connected to the electric grid.

- The biggest contribution of the solar panels is in Autumn and in Spring because we have the lower loads. 


\section{4-SUPERMARKET}

\section{1 - INTRODUCTION}

In this part I am going to design an installation for a supermarket. It only has one floor and it is divided in the purchase zone, the store and an office.

The roof is flat, so the system will be easily installed. On the roof there are some chimneys, air extraction systems and a big area that is not available to install the solar cells.

Finally I am going to design a tracking system because the conditions of the roof permit it.

\section{2-ANALYSIS OF LOADS}

I am going to analyze a medium supermarket. It has the main area to purchase, offices and the store.

\section{A- HEATING - AIR COOLING}

It will have two different systems, once for the supermarket and the other one for the office. We can see this in Table 32.

Table 32. Heating related consumers at the supermarket

\begin{tabular}{|l|c|}
\hline \multicolumn{1}{|c|}{ Description } & Total power \\
\hline 3 heating/Air cooling system (30kW) & $90 \mathrm{~kW}$ \\
\hline Office air conditioning & $10 \mathrm{~kW}$ \\
\hline Total & $100 \mathrm{~kW}$ \\
\hline
\end{tabular}

I include in this part the refrigeration for meat, fish and milk products, and the freezers. We can see this in Table 33.

Table 33. Refrigeration and freezers at the supermarket

\begin{tabular}{|l|c|}
\hline \multicolumn{1}{|c|}{ Description } & Total power \\
\hline 6 refrigeration systems for food & $40 \mathrm{~kW}$ \\
\hline 6 freezers & $20 \mathrm{~kW}$ \\
\hline Total & $60 \mathrm{~kW}$ \\
\hline
\end{tabular}

\section{B- ELEVATORS}

It is not normal have elevators in a supermarket, so I ignore it. 


\section{C- LIGHTING}

I am going to use fluorescents lamps of $36 \mathrm{~W}$. We see the distribution of lamps in Table 34.

Table 34. Distribution of the lights in the supermarket

\begin{tabular}{|l|c|}
\hline \multicolumn{1}{|c|}{ Room } & Number of fluorescents \\
\hline Supermarket & 50 \\
\hline Office & 10 \\
\hline Store & 20 \\
\hline Total & 80 \\
\hline
\end{tabular}

\section{D- INFORMATION TECHNOLOGY}

The supermarket has 4 computers to collect the money of the purchase, another one in the office, a loudspeakers system and 3 automatic doors. The resume of these elements is in Table 35.

Table 35. Technological elements in the supermarket

\begin{tabular}{|l|c|c|c|}
\hline \multicolumn{1}{|c|}{ Description } & Amount & Power & Total power \\
\hline Computers & 5 & $285 \mathrm{~W}$ & $1,43 \mathrm{~kW}$ \\
\hline Automatic doors & 3 & $100 \mathrm{~W}$ & $0,3 \mathrm{~kW}$ \\
\hline Loudspeakers & 6 & $200 \mathrm{~W}$ & $1,2 \mathrm{~kW}$ \\
\hline Microphone & 3 & $80 \mathrm{~W}$ & $0,24 \mathrm{~kW}$ \\
\hline Total & & & $3,17 \mathrm{~kW}$ \\
\hline
\end{tabular}

Finally, the summary of all loads of the supermarket is in Table 36:

Table 36: Total loads in the supermarket

\begin{tabular}{|c|c|c|c|}
\hline Description & Number of elements & Power & Total \\
\hline Fluorescents lamps & 80 & $36 \mathrm{~W}$ & $2,9 \mathrm{~kW}$ \\
\hline Computers & 5 & $285 W$ & $1,43 \mathrm{~kW}$ \\
\hline Automatic doors & 3 & $100 \mathrm{~W}$ & $0,3 \mathrm{~kW}$ \\
\hline Loudspeakers & 6 & $200 W$ & $1,2 \mathrm{~kW}$ \\
\hline Microphone & 3 & $80 \mathrm{~W}$ & $0,24 \mathrm{~kW}$ \\
\hline Refrigeration system for food & 6 & & $40 \mathrm{~kW}$ \\
\hline Freezers & 6 & & $20 \mathrm{~kW}$ \\
\hline Heating/Air cooling system & 3 & $30 \mathrm{~kW}$ & $90 \mathrm{~kW}$ \\
\hline Office air conditioning & 1 & $10 \mathrm{~kW}$ & $10 \mathrm{~kW}$ \\
\hline Total & & & $166,07 \mathrm{~kW}$ \\
\hline
\end{tabular}

The trend of consumption has to be determined during a day, a week and a year. 
- Daily: the supermarket is open during the day, but at night it also has consumption because of the freezers and the refrigeration systems for food. We can see this in Figure 20.

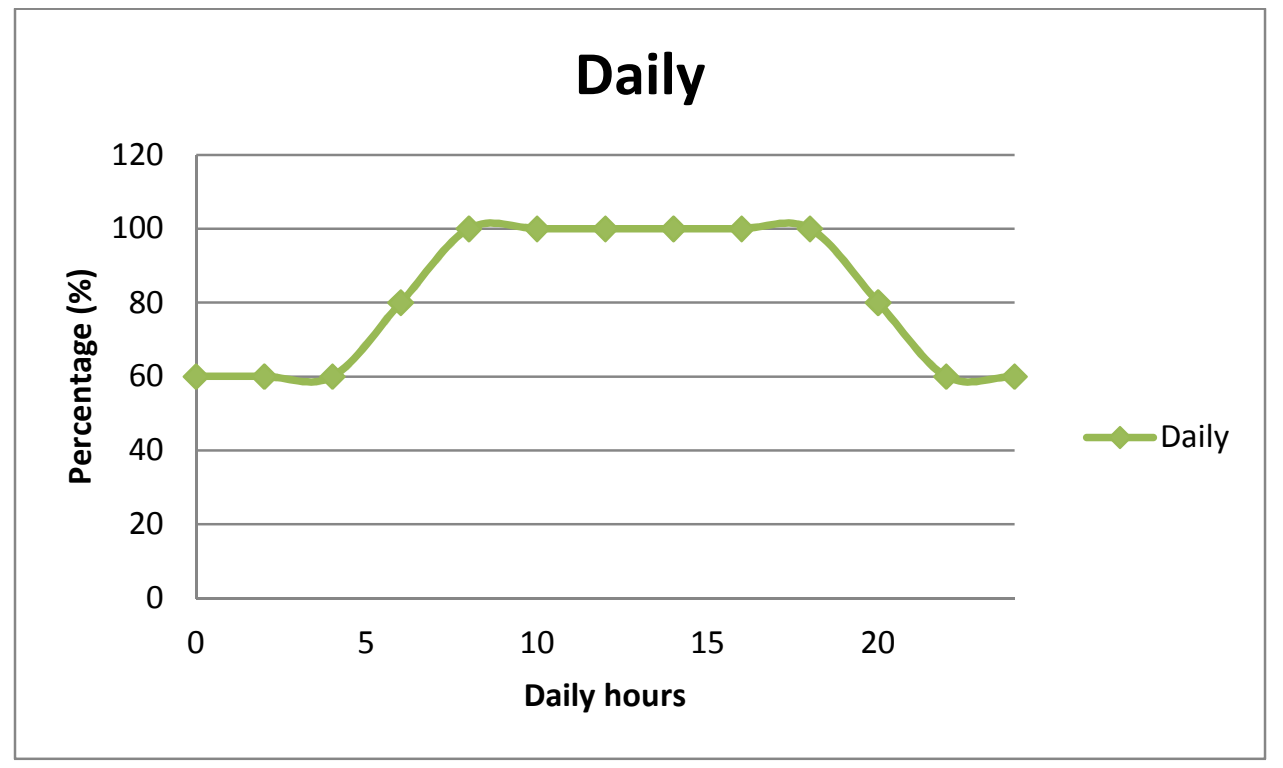

Figure 20. Daily trend of electricity consumption in the supermarket

- Weekly: the supermarket is open less hours on Saturday and it is closed on Sunday, but it needs power to the freezers and refrigeration systems. We can see this in Figure 21.

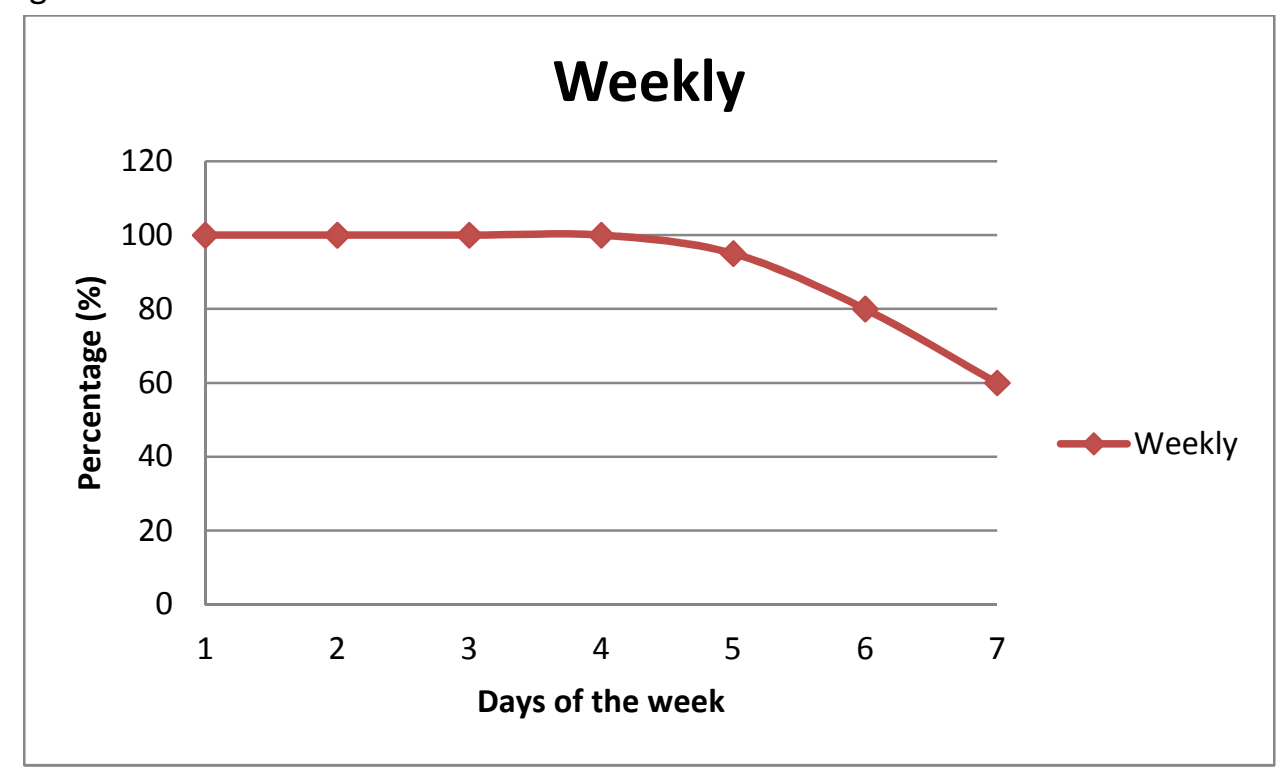

Figure 21. Weekly trend of electricity consumption in the supermarket 
- Yearly: the consumption during all the months is constant. We can see this in Figure 22.

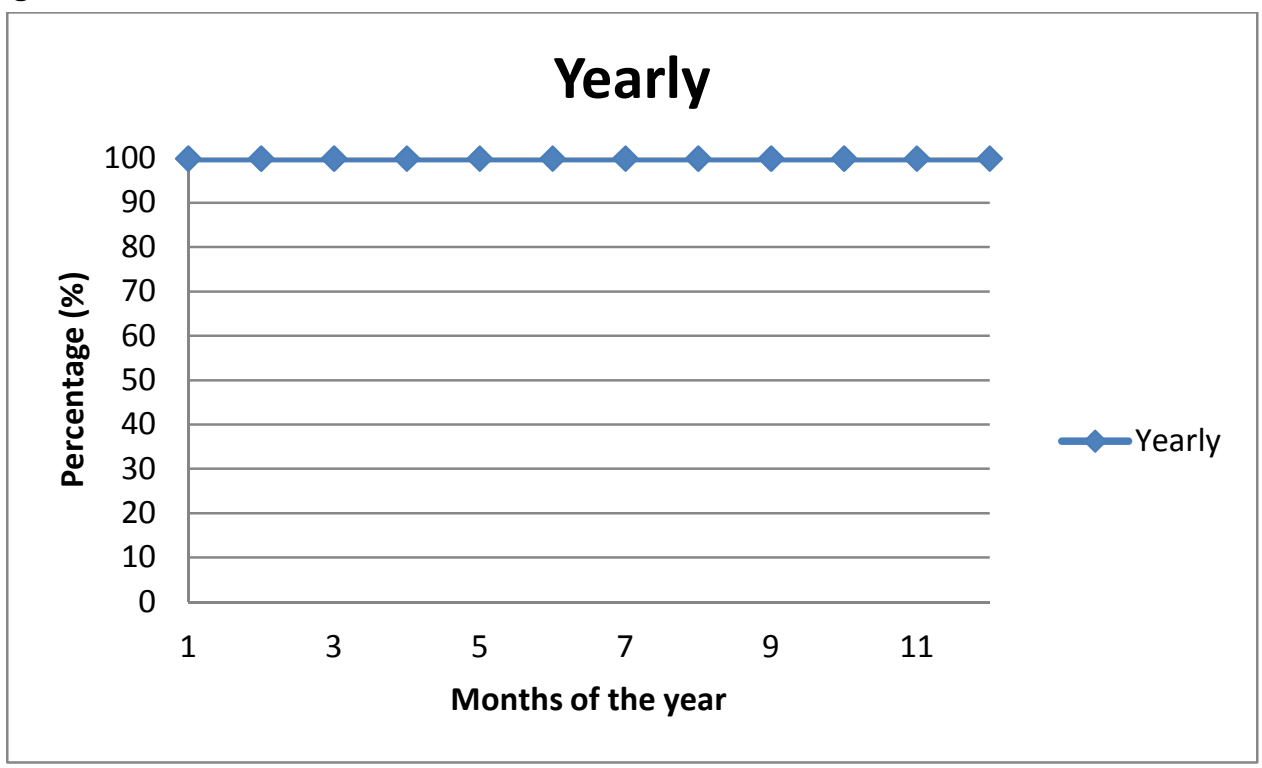

Figure 22. Yearly trend of electricity consumption in the supermarket

\section{3 - STUDY OF THE CHARACTERISTICS OF THE INSTALLATION}

The timetable of the supermarket is the same for all the year, so all the common loads will be the same. The refrigeration system for food and the freezers works 24 hours per day, but I estimate that they work 16 hours with the top power.

1- July and August

The air cooling system for the purchase zone and the office is working during this period. All the loads are resumed in Table 37.

Table 37. Analysis of loads in period 1 in the supermarket

\begin{tabular}{|c|c|c|c|c|}
\hline \multicolumn{5}{|c|}{ July - August } \\
\hline Description & Number of elements & Power & Hours & Total (kWh) \\
\hline Fluorescents lamps & 80 & $36 \mathrm{~W}$ & 12 & 34,56 \\
\hline Computers & 5 & $285 W$ & 12 & 17,1 \\
\hline Automatic doors & 3 & $100 \mathrm{~W}$ & 4 & 1,2 \\
\hline Loudspeakers & 6 & $200 W$ & 3 & 3,6 \\
\hline Microphone & 3 & $80 \mathrm{~W}$ & 3 & 0,72 \\
\hline Refrigeration system for food & 6 & $40 \mathrm{~kW}$ & 16 & 3840 \\
\hline Freezers & 6 & $20 \mathrm{~kW}$ & 16 & 1920 \\
\hline Heating/Air cooling system & 3 & $30 \mathrm{~kW}$ & 5 & 450 \\
\hline Office air conditioning & 1 & $10 \mathrm{~kW}$ & 2 & 20 \\
\hline Total & & & & 6287,18 \\
\hline
\end{tabular}


With the correcting factors I obtain:

$$
G_{1}=\frac{E_{0} \cdot T_{1}}{E_{i}}=\frac{110 \cdot 6287.18}{90}=7684.33 \mathrm{kWh}
$$

2- January, February, March, November and December

The heating system is connected and it needs the same energy than the air cooling system. We can see this in Table 38.

Table 38. Analysis of loads in period 2 in the supermarket

\begin{tabular}{|l|c|c|c|c|}
\hline \multicolumn{5}{|c|}{ January - February - March - November - December } \\
\hline \multicolumn{1}{|c|}{ Description } & Number of elements & Power & Hours & Total (kWh) \\
\hline Fluorescents lamps & 80 & $36 \mathrm{~W}$ & 12 & 34,56 \\
\hline Computers & 5 & $285 \mathrm{~W}$ & 12 & 17,1 \\
\hline Automatic doors & 3 & $100 \mathrm{~W}$ & 4 & 1,2 \\
\hline Loudspeakers & 6 & $200 \mathrm{~W}$ & 3 & 3,6 \\
\hline Microphone & 3 & $80 \mathrm{~W}$ & 3 & 0,72 \\
\hline Refrigeration system for food & 6 & $40 \mathrm{~kW}$ & 16 & 3840 \\
\hline Freezers & 6 & $20 \mathrm{~kW}$ & 16 & 1920 \\
\hline Heating/Air cooling system & 3 & $30 \mathrm{~kW}$ & 5 & 450 \\
\hline Total & \multicolumn{5}{|l}{} & 6267,18 \\
\hline
\end{tabular}

With the correcting factors we obtain:

$$
G_{2}=\frac{E_{0} \cdot T_{2}}{E_{i}}=\frac{110 \cdot 6267.18}{90}=7659.89 \mathrm{kWh}
$$

3- April, May, June, September, October

As we can see in Table 39, it is not necessary the heating system.

Table 39. Analysis of loads in period 3 in the supermarket

\begin{tabular}{|l|r|l|l|r|}
\hline \multicolumn{5}{|c|}{ April - May - June - September - October } \\
\hline Description & Number of elements & Power & Hours & Total (kWh) \\
\hline Fluorescents lamps & 80 & $36 \mathrm{~W}$ & 12 & 34,56 \\
\hline Computers & 5 & $285 \mathrm{~W}$ & 12 & 17,1 \\
\hline Automatic doors & 3 & $100 \mathrm{~W}$ & 4 & 1,2 \\
\hline Loudspeakers & 6 & $200 \mathrm{~W}$ & 3 & 3,6 \\
\hline Microphone & 3 & $80 \mathrm{~W}$ & 3 & 0,72 \\
\hline Refrigeration system for food & 6 & $40 \mathrm{~kW}$ & 16 & 3840 \\
\hline Freezers & 6 & $20 \mathrm{~kW}$ & 16 & 1920 \\
\hline Total & & & & 5817,18 \\
\hline
\end{tabular}


With the correcting factors we obtain:

$$
G_{3}=\frac{E_{0} \cdot T_{3}}{E_{i}}=\frac{110 \cdot 5817.18}{90}=7109.89 \mathrm{kWh}
$$

Once we have the loads of all the year I am going to calculate which month is the most restrictive. With this value I can start to calculate the characteristics of the system, as we can see in Table 40.

Table 40. Comparison of loads and radiation during the year for the supermarket

\begin{tabular}{|c|c|c|c|c|c|c|c|c|c|c|c|c|}
\hline 35ㅇ & J & F & M & A & M & Jn & JI & A & S & O & N & D \\
\hline Rt & 1,47 & 2,23 & 3,37 & 4,08 & 4,27 & 4,39 & 4,53 & 4,31 & 3,51 & 2,93 & 1,73 & 1,16 \\
\hline Gt & 7660 & 7660 & 7660 & 7110 & 7110 & 7110 & 7684 & 7684 & 7110 & 7110 & 7660 & 7660 \\
\hline D & 5211 & 3435 & 2273 & 1743 & 1665 & 1620 & 1696 & 1783 & 2026 & 2427 & 4428 & 6603 \\
\hline
\end{tabular}

The loads of this building are huge for only a photovoltaic system, so it needs be connected to the electric grid. The contribution of solar cells will be only a bit of the needed energy, so I will calculate the maximum number of panels that I can install and after that I will obtain the percentage of contribution.

\section{4- DESIGN OF THE INSTALLATION}

\subsection{1- FIXED SYSTEM}

When I know the loads and the radiation I can start to design the installation of the supermarket. First of all I should calculate the number of photovoltaic cells I need. This amount will be huge due to a lot energy is needed to cover all the necessities. That is the main reason because we are going to install as much panels as I can but the rest of energy will be cover by the electric net.

The roof of the supermarket is a plane surface conducive to the installation of photovoltaic panels. In the roof there is a zone that is not available to put the cells. I divide the other area in two parts to calculate all the available area. The diagram is in Figure 23. 


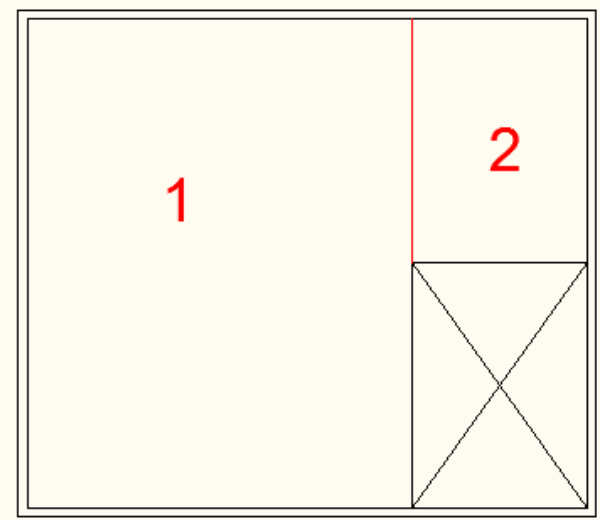

Figure 23. Top view of the roof of the supermarket

The total area of the roof is:

$$
A=33 \cdot 29=957 m^{2}
$$

Where:

- $\quad$ A is the total area of the roof

And the available area is:

$$
\begin{gathered}
A_{1}=25 \cdot 20=500 \mathrm{~m}^{2} \\
A_{2}=15 \cdot 8=120 \mathrm{~m}^{2} \\
A_{T}=A_{1}+A_{2}=500+120=620 \mathrm{~m}^{2}
\end{gathered}
$$

Where:

- $\quad A_{1}$ is the available area of zone 1.

- $\quad A_{2}$ is the available area of zone 2 .

- $\quad A_{T}$ is the available area of all the roof.

Due to the position of the supermarket, the panels with be in a southerly direction with an Azimuth deviation of 10 .

First of all I select the photovoltaic panel Isofoton Isf- 250 with $250 \mathrm{Wp}$. The features are in Table 41.

Table 41. Features of the photovoltaic panel Isofoton Isf-250

\begin{tabular}{|c|c|}
\hline Lengths & $1667 * 994 * 45 \mathrm{~mm}$ \\
\hline Area & $1.657 \mathrm{~m}^{2}$ \\
\hline Weight & $19 \mathrm{~kg}$ \\
\hline Efficiency & $15.1 \%$ \\
\hline Voltage with open circuit & $37.8 \mathrm{~V}$ \\
\hline Current with short circuit & $8.75 \mathrm{~A}$ \\
\hline Voltage with maximum power & $30.6 \mathrm{~V}$ \\
\hline Current with maximum power & $8.17 \mathrm{~A}$ \\
\hline
\end{tabular}


Now, I calculate the minimum distance between panels. We know that latitude of Pécs is 46.07ㅇ. The correct form of calculate this is as we can see in Figure 24.

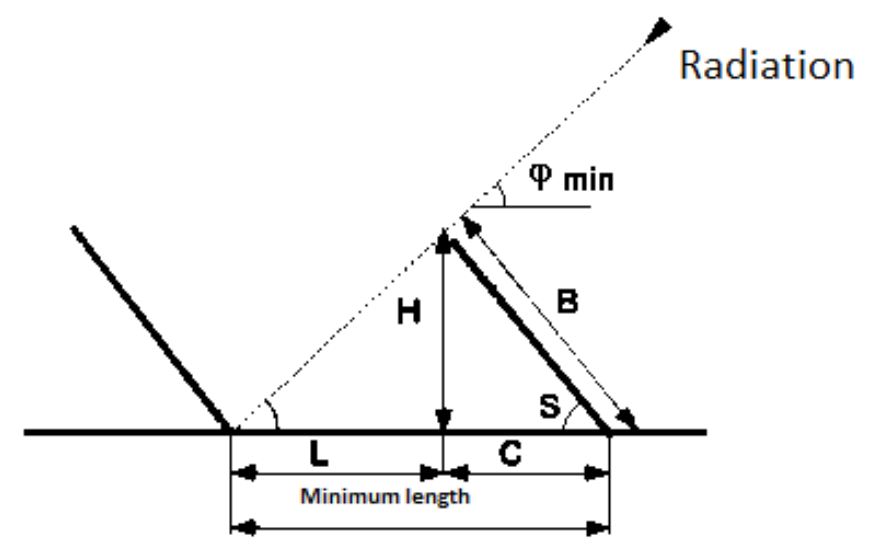

Figure 24. Incidence of radiation

Considering the position and location of the building I obtain:

$$
\begin{gathered}
C=B \cdot \cos 35^{\circ}=0.994 \cdot \cos 35^{\circ}=0.814 m \\
H=B \cdot \sin 35^{\circ}=0.994 \cdot \sin 35^{\circ}=0.57 m \\
\emptyset_{\text {min }}=90^{\circ}-46.07^{\circ}=43.93^{\circ} \\
\tan \emptyset_{\text {min }}=\frac{H}{L}=\frac{B \cdot \sin S}{D_{\text {min }}-B \cdot \cos S} \\
D=B \cdot \cos S+\frac{B \cdot \sin S}{\tan \emptyset_{\text {min }}}=0.994 \cdot \cos 35^{\circ}+\frac{0.994 \cdot \sin 35^{\circ}}{\tan 43.93}=1.406 \mathrm{~m}
\end{gathered}
$$

With this distance I can install 12 lines, 5 of them with 9 panels and the other 7 with 14 panels. So finally the installation will have 143 panels on the roof of the supermarket, as we can see in Figure 25. 


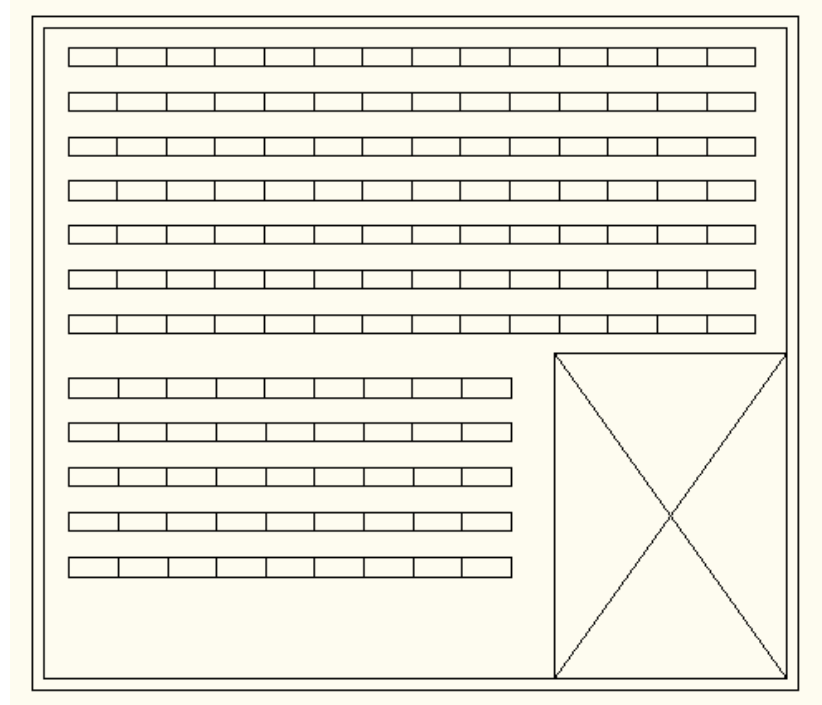

Figure 25. Distribution of the panels for the fixed system on the roof of the supermarket

$$
\text { Total power }=143 \text { panels } \cdot 250 \mathrm{Wp}=35750 \mathrm{Wp}=35.75 \mathrm{kWp}
$$

I divide this amount of power between the irradiation to know the contribution to the system. It is summarized in Table 42.

Table 42. Comparison of loads and radiation for the fixed system in the supermaket

\begin{tabular}{|c|c|c|c|c|c|c|c|c|c|c|c|c|}
\hline 350 & J & F & M & A & M & Jn & Jl & A & S & O & N & D \\
\hline Rt & 1,5 & 2,2 & 3,4 & 4,1 & 4,3 & 4,4 & 4,5 & 4,3 & 3,5 & 2,9 & 1,7 & 1,2 \\
\hline Gt & 35,75 & 35,75 & 35,75 & 35,75 & 35,75 & 35,75 & 35,75 & 35,75 & 35,75 & 35,75 & 35,75 & 35,75 \\
\hline D & 24,32 & 16,03 & 10,61 & 8,76 & 8,37 & 8,14 & 7,89 & 8,29 & 10,19 & 12,20 & 20,66 & 30,82 \\
\hline
\end{tabular}

In Table 43 it is calculated the percentage of contribution for the fixed system:

Table 43. Comparison of percentage of contribution of the fixed system in the supermarket

\begin{tabular}{|c|c|c|c|c|c|c|c|c|c|c|c|c|}
\hline$\%$ & J & F & M & A & M & Jn & Jl & A & S & O & N & D \\
\hline Fixed & 24,3 & 16,0 & 10,6 & 8,8 & 8,4 & 8,1 & 7,9 & 8,3 & 10,2 & 12,2 & 20,7 & 30,8 \\
\hline Total & 5211 & 3435 & 2273 & 1743 & 1665 & 1620 & 1696 & 1783 & 2026 & 2427 & 4428 & 6603 \\
\hline$\%$ & 0,47 & 0,47 & 0,47 & 0,50 & 0,50 & 0,50 & 0,47 & 0,47 & 0,50 & 0,50 & 0,47 & 0,47 \\
\hline
\end{tabular}

Finally I obtain the necessary amount of inverters. The maximum quantity of power is $35.75 \mathrm{kWp}$, so I am going to use 4 inverters Isofoton $10(10 \mathrm{~kW})$ with an efficiency of $96.8 \%$. 


\subsection{2- TRACKING SYSTEM}

The solar tracker is a mechanic device which is used to orient photovoltaic panels, because we would like that they are always perpendicular to the sunlight. Tracking sun from east in the morning to west in the evening will increase the efficiency of the solar panel up to $45 \%$.

These systems have some advantages over the fixed systems:

- They increase the efficiency of the panel.

- Easy installation and startup.

- Different options to the installation.

- Some systems can be controlled by the Internet if you have the appropriate software.

- High solar tracking precision.

- It is suitable for panels with low and high power.

- Low power consumption.

However they also have the disadvantage of being more expensive than the fixed ones.

In this case I have decided for a system with two axes and a pole for the movement and support.

For this installation I am going to use a photovoltaic panel Atersa A-150P, 150W with the features of the Table 44:

Table 44. Features of the photovoltaic panel Atersa A-150P

\begin{tabular}{|c|c|}
\hline Lengths & $1476 * 659 * 35 \mathrm{~mm}$ \\
\hline Area & $0.9727 \mathrm{~m}^{2}$ \\
\hline Weight & $11.9 \mathrm{~kg}$ \\
\hline Efficiency & $15.4 \%$ \\
\hline Voltage with open circuit & $22.6 \mathrm{~V}$ \\
\hline Current with short circuit & $8.69 \mathrm{~A}$ \\
\hline Voltage with maximum power & $17.84 \mathrm{~V}$ \\
\hline Current with maximum power & $8.41 \mathrm{~A}$ \\
\hline
\end{tabular}

I am going to join 9 of these panels to form a group, and each group will be installed on a pole. So, finally the groups are $4428 * 1977 \mathrm{~mm}$ and the total power of each group will be $1350 \mathrm{Wp}$.

The distance between poles has to be calculated, thus I use the same expressions as in the fixed case. I calculate the distances for the two extremes situations, in the sunrise and in the sunset and in noon. 
Option 1: sunrise and sunset:

The North-South distance should only be the lengths of the panels, so I need $4.6 \mathrm{~m}$. On the other hand, to calculate the East-West distance I need the expression that I used in the fixed system. The top inclination of the panel will be 70 , so I use this amount. The explaining picture is in Figure 26.

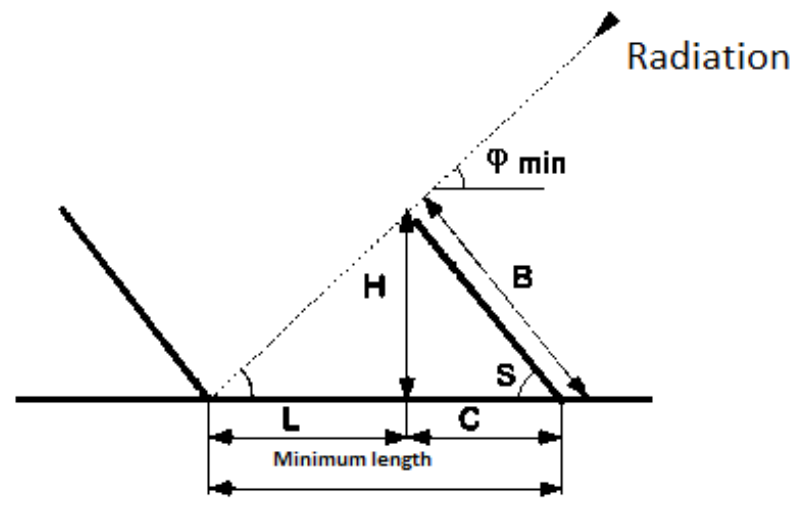

Figure 26. Incidence of radiation

$$
D_{\text {min }}=B \cdot \cos S+\frac{B \cdot \sin S}{\tan \emptyset_{\min }}=1.977 \cdot \cos 70+\frac{1.977 \cdot \sin 70}{\tan 43.93}=2.604 m
$$

Option 2: noon:

In this case the East-West distance is the length of the panels, $4.6 \mathrm{~m}$. I use the expression to calculate the North-South distance.

$$
D_{\text {min }}=B \cdot \cos S+\frac{B \cdot \sin S}{\tan \emptyset_{\min }}=1.977 \cdot \cos 15+\frac{1.977 \cdot \sin 15}{\tan 43.93}=2.44 m
$$

So, finally I need the same separation between poles, a distance of $4.6 \mathrm{~m}$.

The objects on the roof will not disturb the installation of the poles, and they will not have problems with shadows too, because they are higher and sunlight reaches them directly.

It is necessary taking into account that the distance between poles to calculate how many I can install. The available area is in Figure 27: 


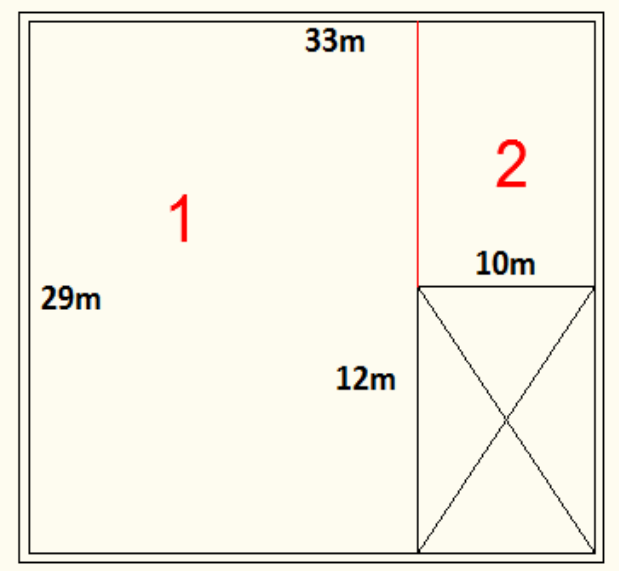

Figure 27. Top view of the available area of the roof of the supermarket

Taking into account the distance between poles I am going to install 36 groups. The scheme is in Figure 28:

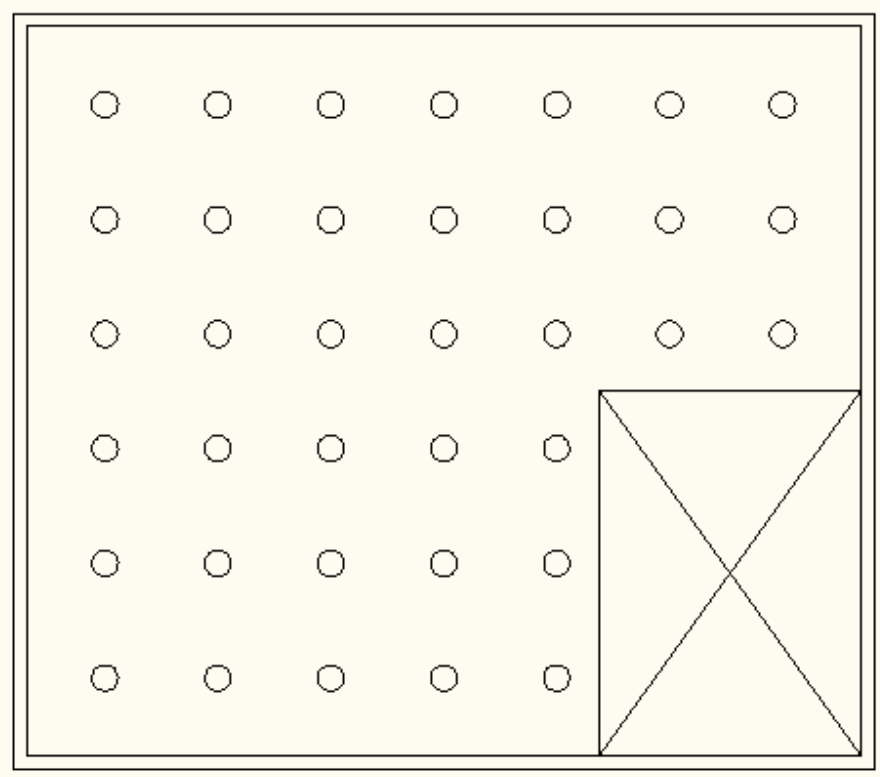

Figure 28. Distribution of the poles for the tracking system on the roof of the supermarket The total power installed is:

$$
\text { Total power }=36 \text { groups } * 1350 \mathrm{Wp}=48600 \mathrm{Wp}=48.6 \mathrm{kWp}
$$

Once I have calculated the power, we have to increase this value depending on the month with corrective factors due to the different quantity of radiation receive in the panels during the day. In Hungary these factors for tracking systems are between 1.3 in winter and 1.8 in summer. I obtain the results of Table 45 for each month. 
Table 45. Total power produced per month in the tracking system in the supermarket

\begin{tabular}{|c|c|c|c|c|c|c|c|c|c|c|c|c|}
\hline \multicolumn{10}{|c|}{ Power per month (kWp) } \\
\hline & J & F & M & A & M & Jn & JI & A & S & O & N & D \\
\hline Factor & 1,3 & 1,4 & 1,48 & 1,65 & 1,65 & 1,75 & 1,8 & 1,8 & 1,7 & 1,6 & 1,45 & 1,3 \\
\hline $\begin{array}{l}\text { Total } \\
\text { power }\end{array}$ & 63,18 & 68,04 & 71,93 & 80,19 & 80,19 & 85,05 & 87,48 & 87,48 & 82,62 & 77,76 & 70,47 & 63,18 \\
\hline
\end{tabular}

Now, I divide this power between the irradiation to see the contribution to the system. We can see this in Table 46.

Table 46. Comparison of loads and radiation for the tracking system in the supermarket

\begin{tabular}{|c|c|c|c|c|c|c|c|c|c|c|c|c|}
\hline Tracking & J & F & M & A & M & Jn & Jl & A & S & O & N & D \\
\hline Rt & 1,79 & 2,71 & 4,17 & 5,32 & 5,81 & 6,09 & 6,26 & 5,87 & 4,42 & 3,65 & 2,09 & 1,38 \\
\hline Power & 63,18 & 68,04 & 71,93 & 80,19 & 80,19 & 85,05 & 87,48 & 87,48 & 82,62 & 77,76 & 70,47 & 63,18 \\
\hline D & 35,3 & 25,11 & 17,25 & 15,07 & 13,8 & 13,97 & 13,97 & 14,9 & 18,69 & 21,3 & 33,72 & 45,78 \\
\hline
\end{tabular}

I obtain the percentage of contribution for the tracking system in Table 47.

Table 47. Comparison of percentage of contribution of the tracking system in the supermarket

\begin{tabular}{|c|c|c|c|c|c|r|r|r|r|c|c|c|}
\hline & J & F & \multicolumn{1}{|c|}{ M } & \multicolumn{1}{|c|}{ A } & M & \multicolumn{1}{c|}{ Jn } & Jl & A & S & O & N & D \\
\hline Tracking & 35,3 & 25,11 & 17,25 & 15,07 & 13,8 & 13,97 & 13,97 & 14,9 & 18,69 & 21,3 & 33,72 & 45,78 \\
\hline Total & 5211 & 3435 & 2273 & 1743 & 1665 & 1620 & 1696 & 1783 & 2026 & 2427 & 4428 & 6603 \\
\hline Percentage & 0,677 & 0,731 & 0,759 & 0,865 & 0,829 & 0,862 & 0,824 & 0,836 & 0,923 & 0,878 & 0,762 & 0,693 \\
\hline
\end{tabular}

Finally I calculate the needed inverters for the system. The maximum quantity of power is $46.17 \mathrm{~kW}$, so I am going to use 5 inverters Isofoton 10 (10kW) with an efficiency of $96.8 \%$.

In this case the installation does not need batteries because the system is connected to the electric grid and the solar cells only support a part of the total power needed. 


\section{5-CONCLUSIONS}

- The main elements of the fixed installation are 143 panels and 4 inverters of $4 \mathrm{~kW}$ each one; for the tracking system we have 36 groups and 5 inverters of $10 \mathrm{~kW}$.

- The comparison of the contribution of the fixed and the tracking system is in Table 48:

Table 48. Comparison of the contribution from the fixed and the tracking system

\begin{tabular}{|l|c|c|c|c|c|c|c|c|c|c|c|c|}
\hline$\%$ & J & F & M & A & M & Jn & Jl & A & S & O & N & D \\
\hline Fixed & 0,467 & 0,467 & 0,467 & 0,503 & 0,503 & 0,503 & 0,465 & 0,465 & 0,503 & 0,503 & 0,467 & 0,467 \\
\hline Tracking & 0,677 & 0,731 & 0,759 & 0,865 & 0,829 & 0,862 & 0,824 & 0,836 & 0,923 & 0,878 & 0,762 & 0,693 \\
\hline
\end{tabular}

As we can see, the contribution of the tracking system is bigger than the contribution of the fixed one.

- The solar system only contributes with a small quantity of power to the system, but during the months we do not have to pay the fee for this power. In big installation like a supermarket the percentage of power contribution is really small.

- The tracking system is more expensive than the fixed one but they produce more energy. Depending on the budget it is possible select one or other. 


\section{$5-\mathrm{CHURCH}$}

\section{1 - INTRODUCTION}

This installation will be design for a small church in a neighborhood in Pécs. The law does not permit to install photovoltaic systems on churches under protection of historic buildings.

The church only has the ground floor, so all the loads will be there. The roof has a slope of 60 은 and I am going to install the cells on this place, so they will have this inclination. In this case the shape of the roof does not permit install tracking system, so I will only analyze the fixed one.

All the system will be isolated, so it is not necessary to connect it to the electric grid. The main elements of the system are going to be the photovoltaic cells, the inverters and also the batteries, because maybe it is needed more energy that the once produced in this moment and it is not possible take it from the net. Finally I am going to use a regulator to prevent the batteries still receive power when it is fully charged.

A scheme of the installation would be as follows in the Figure 29:

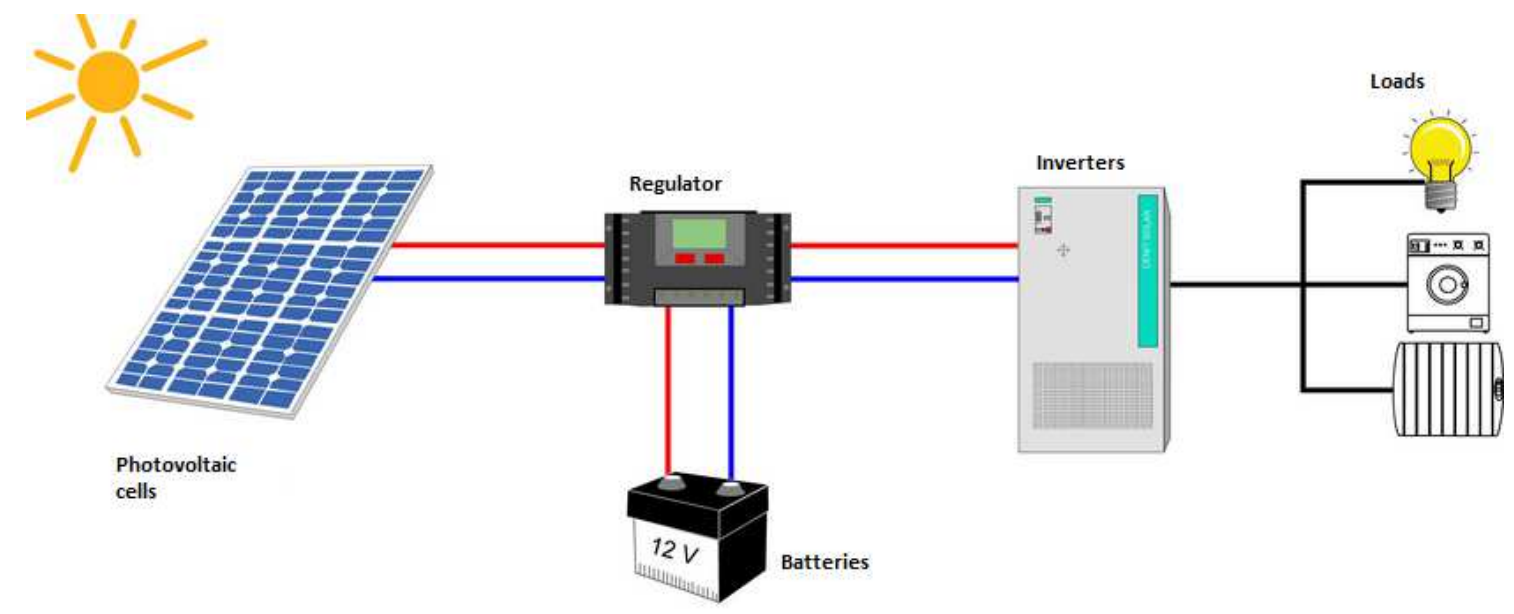

Figure 29. Scheme of the installation

The load during the week has a lot of oscillation because most of the use is during Saturday and Sunday. During winter it is normal to switch on the heating system one hour before the masses. 


\section{2-ANALYSIS OF LOADS}

\section{A- HEATING - AIR COOLING}

The church does not have a heating system and it only has 4 electric heaters ( 3 in the main area of the church and the other one in the sacristy). We can see this in Table 49.

Table 49. Heating related consumers at the church

\begin{tabular}{|l|c|}
\hline \multicolumn{1}{|c|}{ Description } & Total power \\
\hline 4 electric heaters (2000W each one) & $8000 \mathrm{~W}$ \\
\hline Total & $8 \mathrm{~kW}$ \\
\hline
\end{tabular}

\section{B- ELEVATORS}

Small churches rarely have elevator, so it is not included in this case.

\section{C- LIGHTING}

The building is divided in different places: the main area and the sacristy. I am going to use bulbs of $12 \mathrm{~W}$. We can see the distribution in Table 50 .

Table 50. Distribution of the lights in the church

\begin{tabular}{|l|c|c|c|}
\hline \multicolumn{1}{|c|}{ Room } & Number of rooms & Number of bulbs & Total \\
\hline Main area & 1 & 50 & 50 \\
\hline Sacristy & 1 & 10 & 10 \\
\hline Total & & & 60 \\
\hline
\end{tabular}

\section{D- INFORMATION TECHNOLOGY}

It is necessary to install a loudspeakers system in the main area. I also include a radio in the sacristy for the priest. We can see this in Table 51.

Table 51. Technological elements in the church

\begin{tabular}{|l|c|c|c|}
\hline \multicolumn{1}{|c|}{ Description } & Amount & Power & Total power \\
\hline Loudspeakers & 12 & $400 \mathrm{~W}$ & $4,8 \mathrm{~kW}$ \\
\hline Microphone & 2 & $80 \mathrm{~W}$ & $0,16 \mathrm{~kW}$ \\
\hline Radio & 1 & $100 \mathrm{~W}$ & $0,1 \mathrm{~kW}$ \\
\hline Total & & & $5,06 \mathrm{~kW}$ \\
\hline
\end{tabular}


Finally, the summary of all building loads is in Table 52:

Table 52: Total loads in the church

\begin{tabular}{|c|c|c|c|}
\hline Description & Number of elements & Power & Total \\
\hline Heaters & 4 & 2000W & $8 \mathrm{~kW}$ \\
\hline Bulbs & 60 & $12 \mathrm{~W}$ & $0,72 \mathrm{~kW}$ \\
\hline Loudspeakers & 12 & $400 W$ & $4,8 \mathrm{~kW}$ \\
\hline Microphone & 2 & $80 \mathrm{~W}$ & $0,16 \mathrm{~kW}$ \\
\hline Radio & 1 & $100 \mathrm{~W}$ & $0,1 \mathrm{~kW}$ \\
\hline Total & & & $13,78 \mathrm{~kW}$ \\
\hline
\end{tabular}

The graphs of loads are as follows.

- Daily: the top of the loads is during the day. At night the church is closed, as we can see in Figure 30.

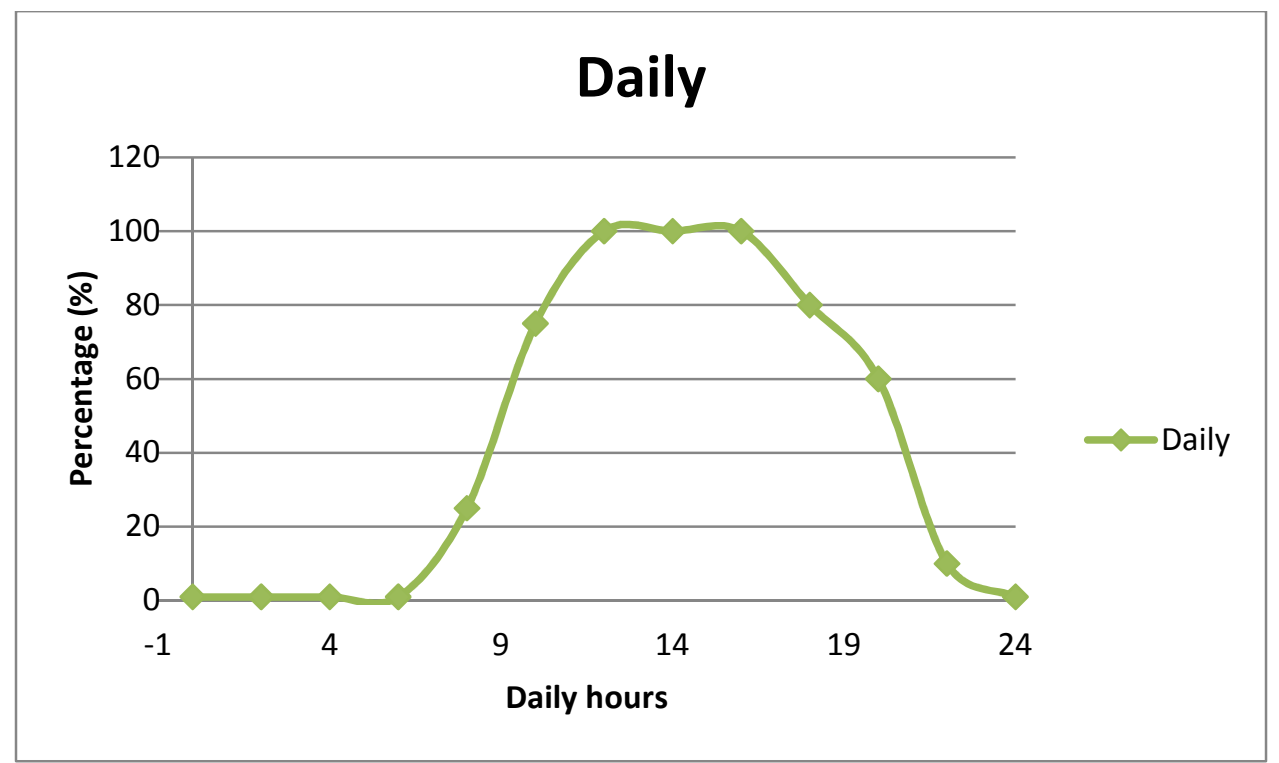

Figure 30. Daily trend of electricity consumption in the church 
- Weekly: the peak of consumption is at the weekend, especially on Sunday. We can see this in Figure 31.

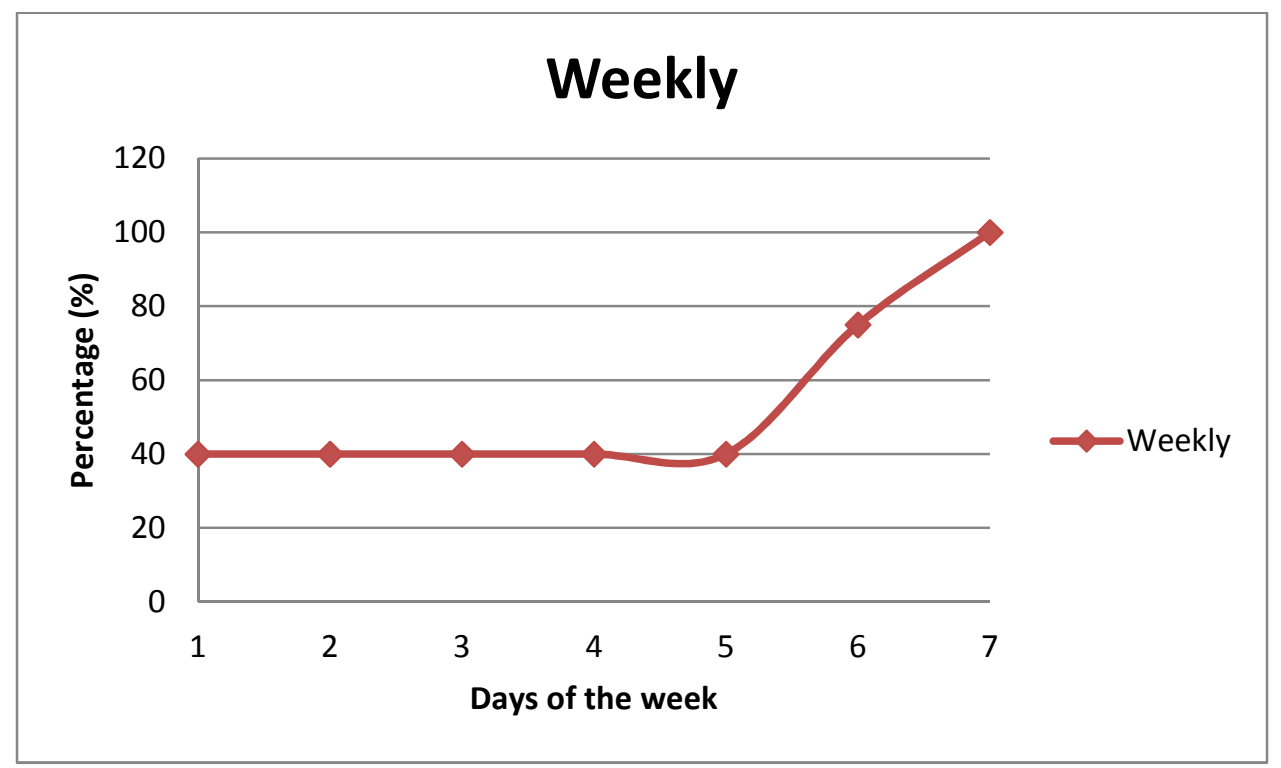

Figure 31. Weekly trend of electricity consumption in the church

Yearly: it is a big difference between winter and summer because of the electric heaters. In the rest of places the differences are not so bigger because I suppose that the other buildings also have air cooling system. We can see this in Figure 32 .

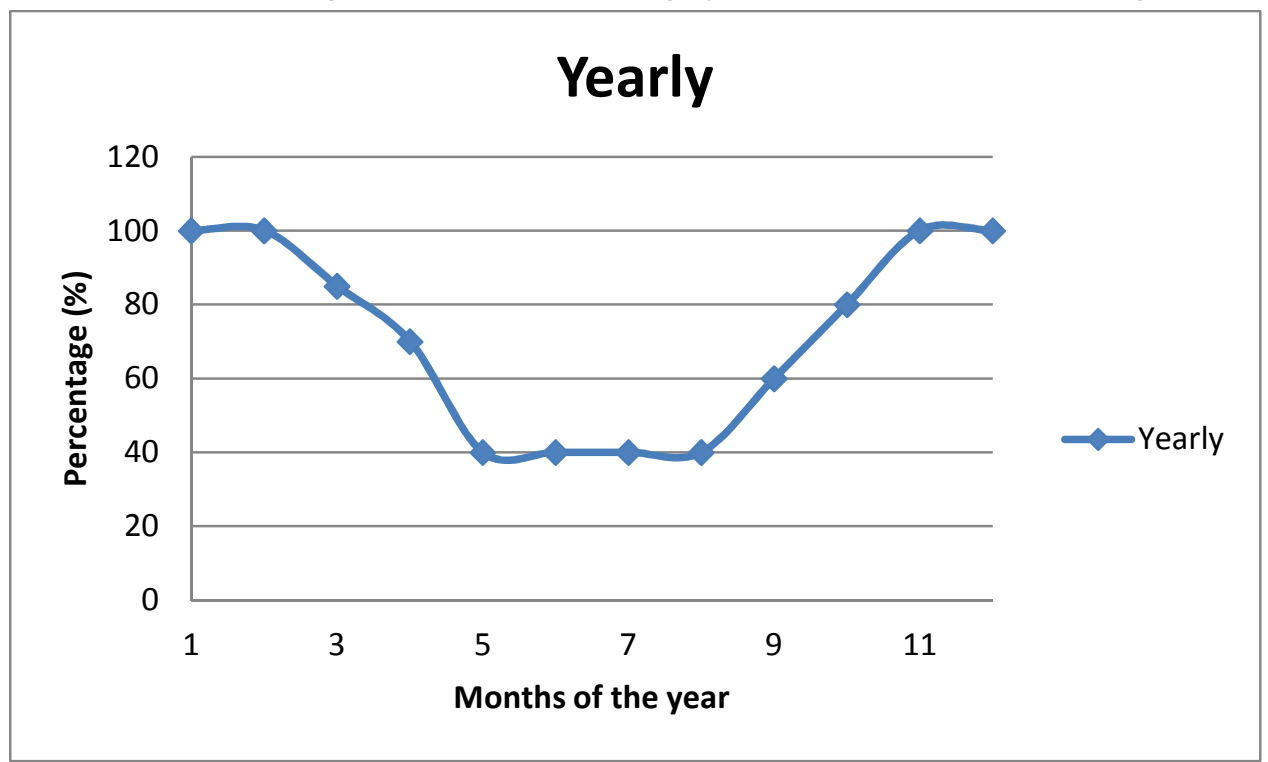

Figure 32. Yearly trend of electricity consumption in the church 


\section{3- STUDY OF THE CHARACTERISTICS OF THE INSTALLATION}

I divide the months in two groups depending on the heaters. I am going to suppose that all the days of the week are similar, that is why the number of hours is very small, because at the weekends the church will be open more time than during the week.

1- January, February, March, November, December

During these months we need the heaters, as we can see in Table 53.

Table 53. Analysis of loads in period 1 in the church

\begin{tabular}{|l|rr|l|l|r|}
\hline \multicolumn{7}{|c|}{ January - February - March - November - December } \\
\hline Description & Number of elements & Power & Hours & Total (kWh) \\
\hline Heaters & 4 & 2000W & 1 & 8 \\
\hline Bulbs & 60 & 12W & 3 & 2,16 \\
\hline Loudspeakers & 12 & $400 \mathrm{~W}$ & 0,5 & 2,4 \\
\hline Microphone & 2 & 80W & 0,5 & 0,08 \\
\hline Radio & 1 & 100W & 0,5 & 0,05 \\
\hline Total & & & & 12,69 \\
\hline
\end{tabular}

I use the correcting factors.

$$
G_{1}=\frac{E_{0} \cdot T_{1}}{E_{i}}=\frac{110 \cdot 12.69}{90}=15.51 \mathrm{kWh}
$$

\section{2- April, May, June, July, August, September, October}

It is not necessary use the heaters, so the energy is lower than in the other case. We see this in Table 54.

Table 54. Analysis of loads in period 2 in the church

\begin{tabular}{|l|lr|l|l|r|}
\hline \multicolumn{5}{|c|}{ April - May - June - July - August - September - October } \\
\hline Description & Number of elements & Power & Hours & Total (kWh) \\
\hline Bulbs & 60 & $12 \mathrm{~W}$ & 3 & 2,16 \\
\hline Loudspeakers & 12 & $400 \mathrm{~W}$ & 0,5 & 2,4 \\
\hline Microphone & 2 & $80 \mathrm{~W}$ & 0,5 & 0,08 \\
\hline Radio & 1 & $100 \mathrm{~W}$ & 0,5 & 0,05 \\
\hline Total & \multicolumn{7}{|l}{} & & 4,69 \\
\hline
\end{tabular}

We use the correcting factors again.

$$
G_{2}=\frac{E_{0} \cdot T_{2}}{E_{i}}=\frac{110 \cdot 4.69}{90}=5.73 \mathrm{kWh}
$$




\section{4- DESIGN OF THE INSTALLATION}

In this case I am going to overlay the panels on the roof. So I need the radiation for 600 , because it is the inclination of the roof. We obtain the comparison between loads and radiation in Table 55.

Table 55. Comparison of loads and radiation during the year for the church

\begin{tabular}{|c|c|c|c|c|c|c|c|c|c|c|c|c|}
\hline 60 ㅇ & J & F & M & A & M & Jn & JI & A & S & O & N & D \\
\hline Rt & 2,05 & 3,19 & 4,03 & 4,76 & 4,94 & 4,89 & 5,03 & 5,08 & 4,44 & 3,79 & 2,45 & 1,6 \\
\hline Gt & 15,51 & 15,51 & 15,51 & 5,73 & 5,73 & 5,73 & 5,73 & 5,73 & 5,73 & 5,73 & 15,51 & 15,51 \\
\hline D & 7,57 & 4,86 & 3,85 & 1,20 & 1,16 & 1,17 & 1,14 & 1,13 & 1,29 & 1,51 & 6,33 & 9,69 \\
\hline
\end{tabular}

Such as in the other buildings I am going to use the photovoltaic panel Isofoton Isf-250 with $250 \mathrm{Wp}$. It has the characteristics written in Table 56.

Table 56. Features of the photovoltaic panel Isofoton Isf-250

\begin{tabular}{|c|c|}
\hline Lengths & $1667 * 994 * 45 \mathrm{~mm}$ \\
\hline Area & $1.657 \mathrm{~m}^{2}$ \\
\hline Weight & $19 \mathrm{~kg}$ \\
\hline Efficiency & $15.1 \%$ \\
\hline Voltage with open circuit & $37.8 \mathrm{~V}$ \\
\hline Current with short circuit & $8.75 \mathrm{~A}$ \\
\hline Voltage with maximum power & $30.6 \mathrm{~V}$ \\
\hline Current with maximum power & $8.17 \mathrm{~A}$ \\
\hline
\end{tabular}

The orientation of the church is East-West, so I am going to install de panels in the Southern direction with an Azimuth of 5․ An approximately scheme of the church is in Figure 33.

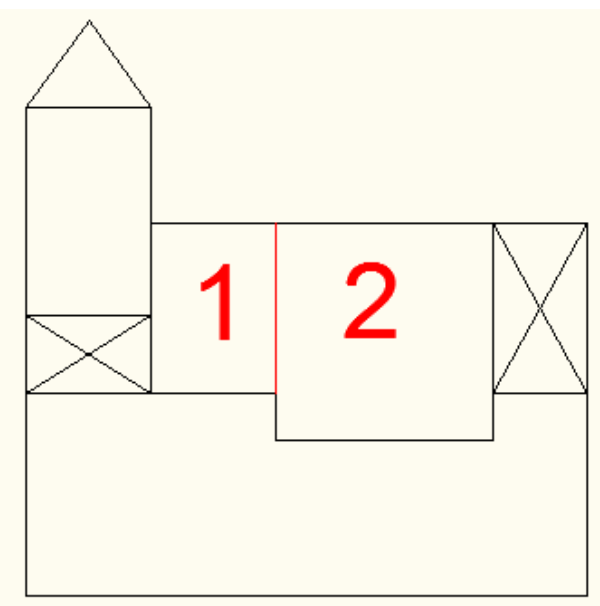

Figure 33. Available area of the roof of the church 
Zones 1 and 2 are where the panels will be installed. In the part with the cross I prefer do not install anything because it is curve and the orientation is not good. The available total area is $95.6 \mathrm{~m}^{2}$.

Now I to obtain the needed area:

$$
S=\frac{1.1 \cdot D}{\rho}=\frac{1.1 \cdot 9.69}{0.151}=70.59 \mathrm{~m}^{2}
$$

Where:

- $\quad S$ is the total area

- $\quad D$ is the relation between $R_{t}$ and $G_{t}$. Measurement unit: $m^{2}$

- $\quad \rho$ is the efficiency of the panel.

$$
\text { Number of panels }=\frac{S}{A}=\frac{70.59}{1.667 \cdot 0.994}=42.6 \rightarrow 43 \text { panels }
$$

Where:

- $\quad \mathrm{S}$ is the total area.

- $\quad$ A is the area of each panel

$$
\text { Total power }=250 \mathrm{Wp} \cdot 43 \text { panels }=10750 \mathrm{Wp}=10.75 \mathrm{kWp}
$$

We can see the position of the panels in Figure 34 .

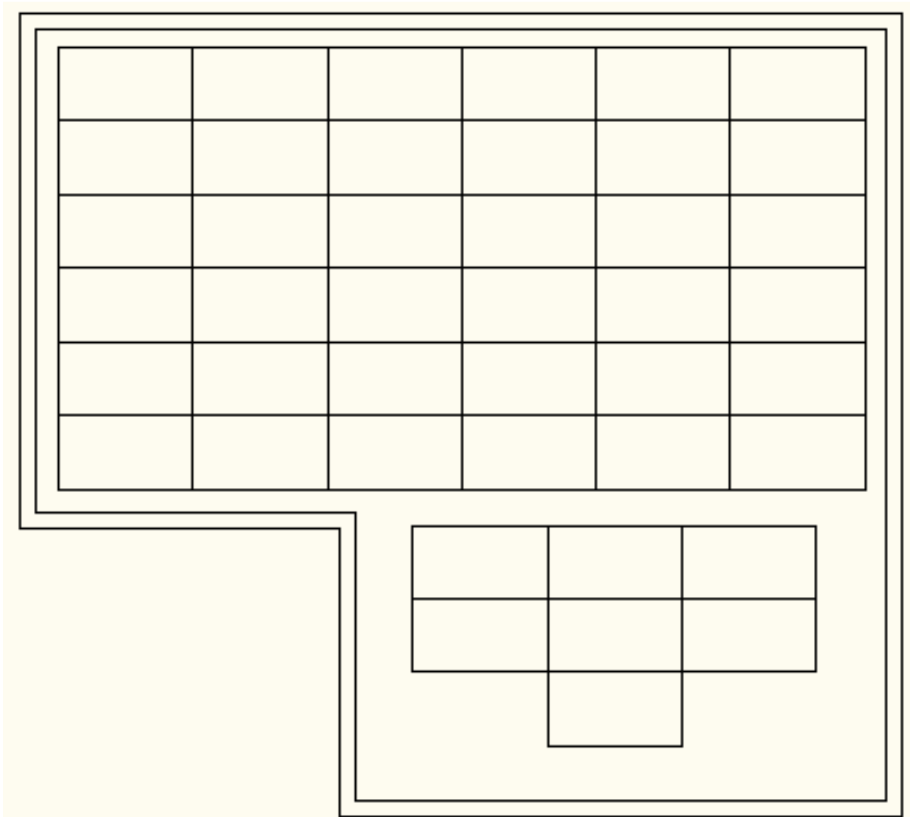

Figure 34. Distribution of the panels on the roof of the church 
Once I have calculated the number of panels, I select the inverters. For this problem we suppose that all the loads are connected at the same time. Due to it is normal in a church have everything connected during the masses we have the results in Table 56.

Table 56. Total loads of the church

\begin{tabular}{|c|c|c|c|}
\hline Description & Number of elements & Power & Total \\
\hline Heaters & 4 & $2000 \mathrm{~W}$ & $8 \mathrm{~kW}$ \\
\hline Bulbs & 60 & $12 \mathrm{~W}$ & $0,72 \mathrm{~kW}$ \\
\hline Loudspeakers & 12 & $400 W$ & $4,8 \mathrm{~kW}$ \\
\hline Microphone & 2 & $80 W$ & $0,16 \mathrm{~kW}$ \\
\hline Radio & 1 & $100 W$ & $0,1 \mathrm{~kW}$ \\
\hline Total & & & $13,78 \mathrm{~kW}$ \\
\hline
\end{tabular}

It is not possible to have so bigger inverters, so I use three inverters Isofoton 5 (5 kW), obtaining a maximum of $15 \mathrm{~kW}$.

Finally I need obtain the number of batteries needed. Each battery will have $48 \mathrm{~V}$ in total and $2 \mathrm{~V}$ for each section inside it, so I need 24 sections for each battery. We select the model Rolls 48V S460 460Ah C100 with maximum discharge capacity of $70 \%$.

Now I obtain the accumulation capacity:

$$
C_{100}=\frac{110 \cdot G \cdot D}{T \cdot M}=\frac{110 \cdot 15510 \cdot D}{48 \cdot 70}=507 \cdot D A h
$$

Where:

- $\quad \mathrm{C}_{100}$ is the accumulation capacity

- $\quad G$ is the energy with correcting factors

- D are the days of autonomy

- $\quad T$ is the voltage

- $\quad M$ is the maximum capacity of discharge

We have to calculate the autonomy days with some tests:

- Load current:

$$
I_{\text {load }}<10 \% \cdot C_{100}
$$

Where:

- $\mathrm{I}_{\text {load }}$ is the current to load

- $\mathrm{C}_{100}$ is the accumulation capacity 


$$
I_{\text {load }}=\frac{C T}{T}=\frac{10750}{48}=223.96 A<50.7 \cdot D \rightarrow D>4.42 \text { days }
$$

Where:

- $\mathrm{I}_{\text {load }}$ is the current to load

- CT is the total power of the panels

- $\mathrm{T}$ is the voltage

Download current:

$$
I_{\text {download }}<10 \% \cdot C_{100}
$$

Where:

- $I_{\text {download }}$ is the current to download

- $\mathrm{C}_{100}$ is the accumulation capacity

$$
I_{\text {download }}=\frac{P_{\text {inv }}}{T}=\frac{15000}{48}=312.5 A<50.7 \cdot D \rightarrow D>6.16 \text { days }
$$

Where:

- $I_{\text {download }}$ is the current to download

- $P_{\text {inv }}$ is the total power of the panels

$\circ \quad T$ is the voltage

Night loads:

$$
\text { Night loads }<20 \% \cdot C_{100}
$$

Where:

- $C_{100}$ is the accumulation capacity

$$
\text { Night loads }=\frac{G_{\text {night }}}{T}=0 \rightarrow D>0 \text { days }
$$

Where:

- $G_{\text {night }}$ is the total loads at night

$\circ \mathrm{T}$ is the voltage

So, finally it is necessary have batteries with 7 autonomy days.

The accumulation capacity is:

$$
C_{100}=507 \cdot D A h=507 \cdot 7=3549 A h
$$

Now I obtain the number of batteries:

$$
\text { Number of batteries }=\frac{3549}{460}=7.7 \rightarrow 8 \text { batteries }
$$




\section{5- CONCLUSIONS}

- The main elements of the installation are 43 solar panels, 3 inverters, 1 regulator and 8 batteries.

- The installation is isolated, so all the power will be produced by this elements.

- During winter we have the biggest amount of power needed and the lowest amount of energy produced, so we need the batteries full charged for this period of time. In summer we do not have this problem because the quantity of radiation is bigger.

- The solar panels are only faces Southern because it is the best option. It has no sense put it faces Northern because they will not have a good efficiency.

- It is not necessary power lines because the energy will be consumed in the same place where it is produced.

- We have to pay the initial investment but after that we do not have to pay monthly instalments. 


\section{6- COMPARISON OF THE CONSUMPTIONS}

I am going to probe that the consumption of the different buildings is really different.

- Yearly: we can see that the office and the faculty have the same graphic of consumption. The amount of power needed oscillate because of the summer holidays. The church varies too, but this is because we consider that it is not necessary the air cooling and the electric heaters need a lot of energy to work correctly. On the other hand the consumption of the supermarket is always the same more or less during the year. We can see this in the Figure 35.

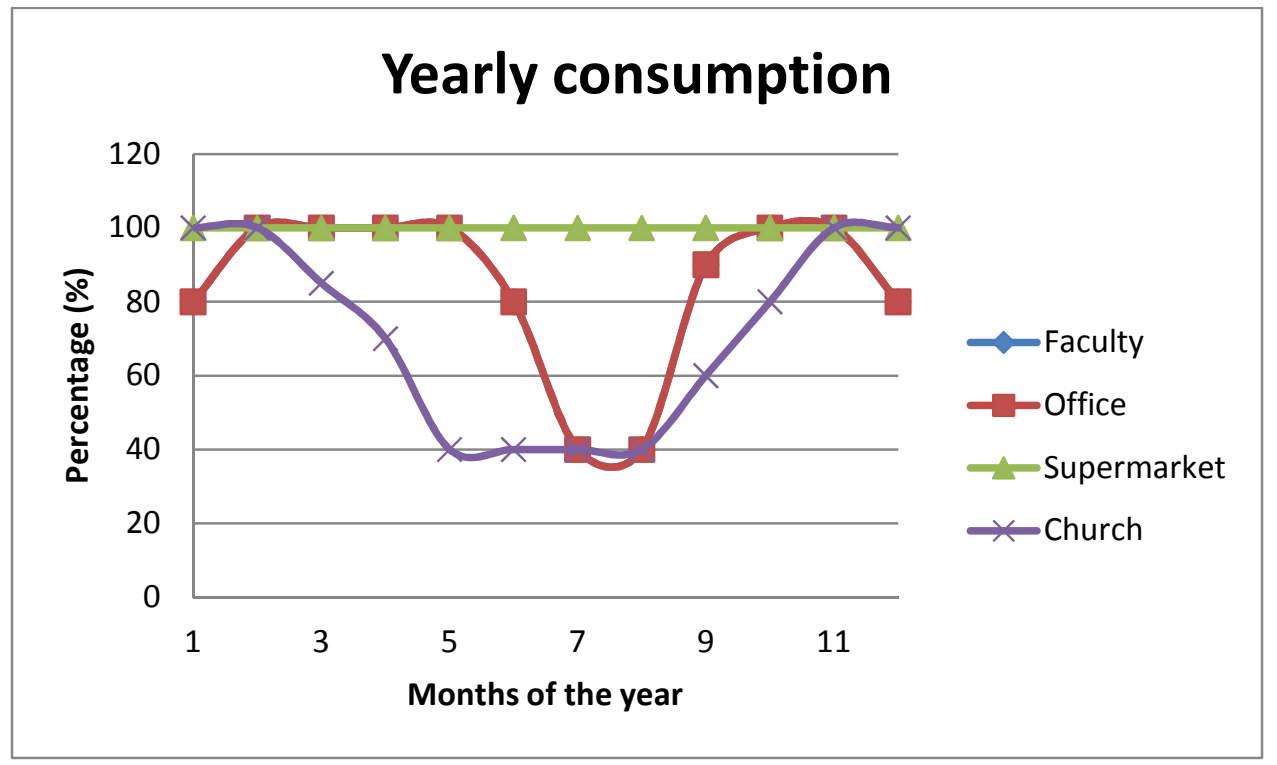

Figure 35. Comparison of the consumptions during a year

- Weekly: we can see that all the buildings have their top of consumption during the week. The exception is the church because most ceremonies are during the weekend, as we can see in the Figure 36.

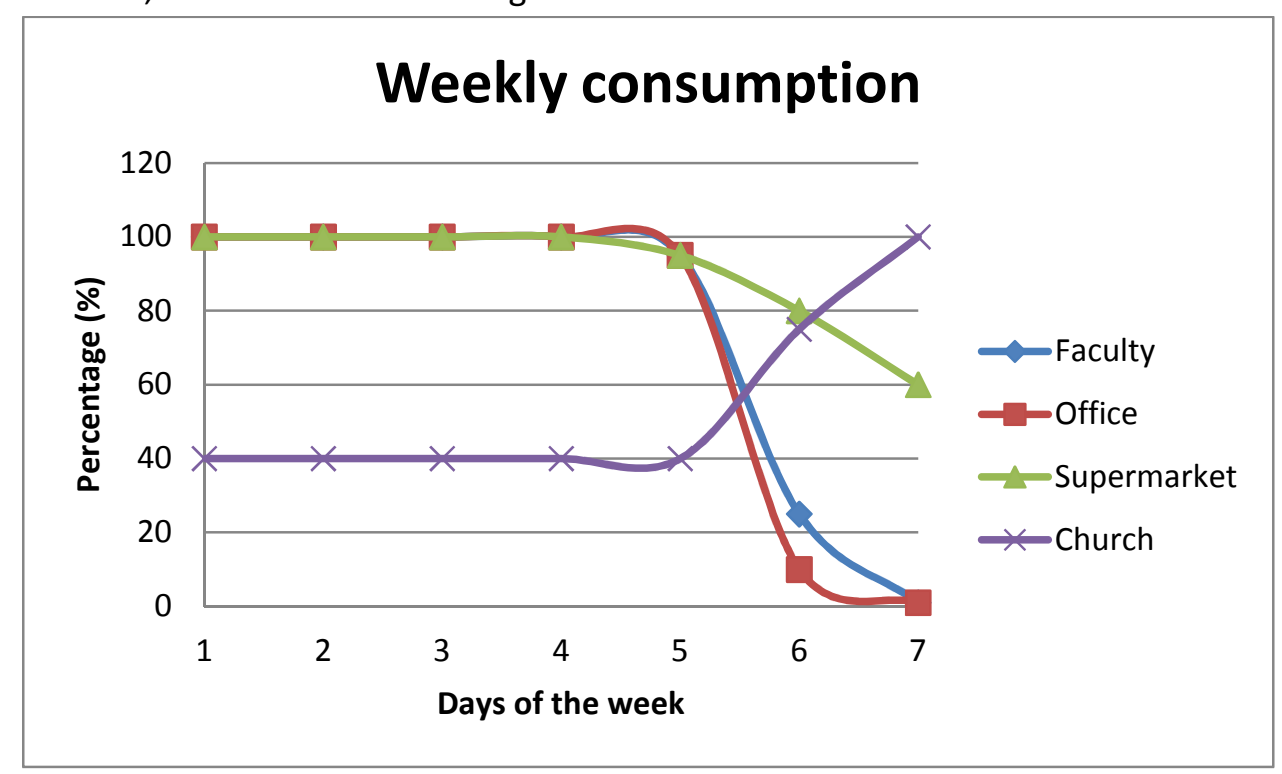

Figure 36. Comparison of the consumptions during a week 
- Daily: during the day all the buildings have a similar graph, but the supermarket has its minimum at the $60 \%$ of consumption because of the freezers and the refrigeration systems. We can see this in the Figure 37.

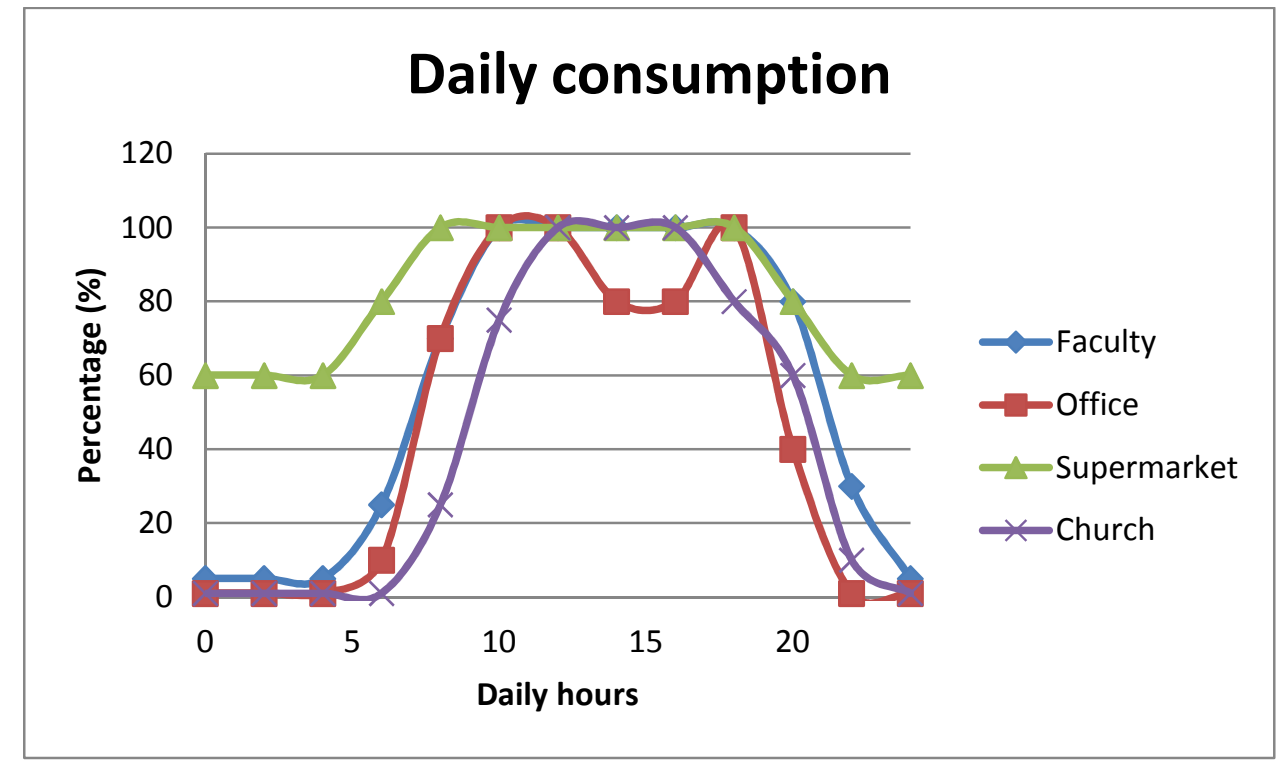

Figure 37. Comparison of the consumptions during a day 


\section{7- REFERENCES}

1- "Interactive book about solar energy and its applications". Danny Andrés Arenas Sánchez and Hodman Steven Zapata Castaño. University of Pereira, Faculty of Technology. Electrical Technology Program. 2011

2- http://www.miliarium.com/Bibliografia/Monografias/Energia/EnergiasRenovables/Ene rgiaSolarFotovoltaica.asp

3- Website http://re.jrc.ec.europa.eu/pvgis/

4- Website http://www.solar-tracking.es/

5- Website http://www.suntracking.es/en

6- Website http://www.isofoton.com/sites/default/files/250-black es .pdf

7- Website http://www.atersa.com/img/201328103610.pdf

8- Website http://www.isofoton.com/sites/default/files/isokit web .pdf

9- Website https://autosolar.es/baterias/bateria-48v/bateria-rolls-48v-460ahs460_precio

10- Notes of the subject "Renewable Energies". University of Valladolid, Spain. 